FACULDADE DE CIÊNCIAS ECONô MICAS dA UFRGS
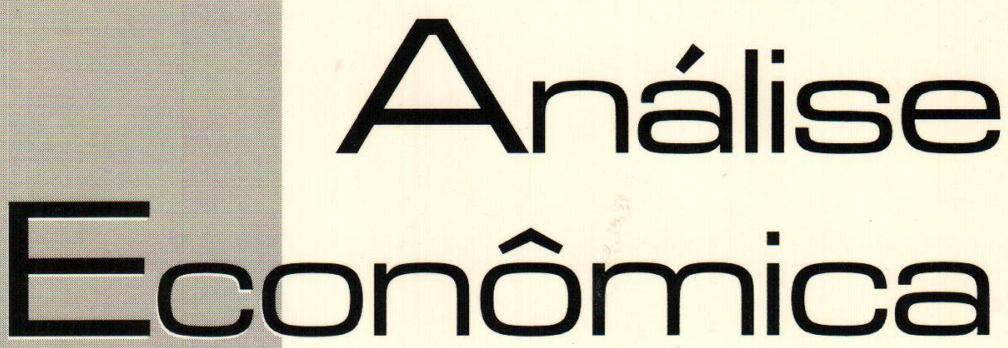

ESCOLHA DE PORTFÓLIO, INVESTIMENTO E NĀO. NEUTRALIDADE DA MOEDA

JOSÉ LUIS OREIRO

REFORMAS NA AROUITETURA FINANCEIRA INTERNACIONAL: NOVIDADES NO FRONT? ANDRÉ MOREIRA CUNHA

MERCOSUR'S CHANGE IN TRADE PATTERNS ANDRÉ FILIPE ZAGO DE AZEVEDO

O IMPACTO DA COMPOSICÃO SETORIAL, DOS FLUXOS INTRA-SETORIAIS E DA ABERTURA COMERCIAL NA PARTICIPAÇÁO DE MERCADO DAS EXPORTAÇÓES BRASILEIRAS

CLÉSIO LOURENÇO XAVIER E EMERSON FERNANDES MARÇAL

O EFEITO BALASSA-SAMUELSON E A PARIDADE DO PODER DE COMPRA NA ECONOMIA BRASILEIRA CLÁUDIO ROBERTO FÓFFANO VASCONCELOS

CICLOS Y FLUCTUACIONES FINANCIERAS: LA IRREGULAR DINÁMICA ECONÓMICA

SARY LEVY-CARCIENTE

O PENSAMENTO DE KARL POPPER: AS DIFERENTES INTERPRETACÓES DOS METODÓLOCOS DA CIENCIA ECONÓMICA

SOLANCE REGINA MARIN E RAMÓN GARCÍA FERNÁNDEZ

A EXPANSÃO DO ESCOPO TEMÁTICO DAS NEGOCIAÇÓES COLETIVAS DE TRABALHO CARLOS HENRIQUE HORN

EFEITOS DO CAPITAL SOCIAL E DO CAPITAL POLITICO NO DESENVOLVIMENTO ECONOMMICO SIMULAÇOES PARA PAISES E ESTADOS BRASILEIROS

RONALDO A. ARRAES, RICARDO CANDÉA S. BARRETO E VLADIMIR KÜHL TELES

O PROBLEMA DE RISCO MORAL NO MERCADO BRASILEIRO DE ASSISTÊNCIA MÉDICA SUPLEMENTAR LUCIANA PINTO DE ANDRADEE SABINO DA SILVA PÓRTO JÚNIOR

ANO

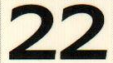

No 41

Março, 2004 
Universidade Federal do Rio Grande do Sul

Reitora: Profo. Wrana Maria Panizzi

Faculdade de Ciencias ECONOMICAS

Diretora: Prof Pedro César Dutra Fonseca

Centro de Estudos e Pesquisas Economicas

Diretor: Prof. Gentil Corazza

Departamento de Ciencias Económicas

Chefe: Prof. Ricardo Dathein

Curso de Pós-Graduação em Economia

Coordenador: Prof. Eduardo Pontual Ribeiro

Programa de Pó-Graduação em Desenvolvimento Rural

Coordenador: Prof. Jalcione Almeida

CONSElHo EDITORIAL:

Carlos G. A. Mielitz Netto (UFRGS), Eduardo A. Maldonado Filho (UFRGS), Eduardo P. Ribeiro (UFRGS), Eleutério F. S. Prado (USP), Eugênio Lagemann (UFRGS), Fernando Cardim de Carvalho (UFRJ), Fernando Ferrari Filho (UFRGS), Fernando de Holanda Barbosa (FGV/RJ), Flávio Vasconcellos Comim (UFRGS), Gentil Corazza (UFRGS), Giácomo Balbinotto Netto (UFRGS), Gustavo Franco (PUC/RJ), Jan A. Kregel (UNCTAD), João Rógério Sanson (UFSC), Joaquim Pinto de Andrade (UnB), Jorge Paulo Araújo (UFRGS), Juan H. Moldau (USP), Marcelo S. Portugal (UFRGS), Maria Alice Lahorgue (UFRGS), Paul Davidson (University of Tennessee), Paulo D. Waquil (UFRGS), Pedro C. D. Fonseca (UFRGS), Philip Arestis (Levy Economics Institut of Bard College), Roberto C. de Moraes (UFRGS), Ronald Otto Hillbrecht (UFRGS), Sabino da Silva Porto Jr. (UFRGS), Stefano Florissi (UFRGS) e Werner Baer (University of Illinois at Urbana-Champaign).

COMISSĀO EDITORIAL:

Eduardo Augusto Maldonado Filho, Fernando Ferrari Filho, Gentil Corazza, Marcelo Savino Portugal, Paulo Dabdab Waquil e Roberto Camps Moraes.

EDITOR: Prof. Fernando Ferrari Filho

Editor Adjunto: Prof. Gentil Corazza

SeCretária: Paulo Roberto Eckert

REVISÃO DE TEXTOS: Vanete Ricacheski

EdITORAÇÃo Eletrónca: Vanessa Hoffmann de Quadros

Fundador: Prof. Antônio Carlos Santos Rosa

Os materiais publicados na revista Análise Econômica são da exclusiva responsabilidade dos autores. É permitida a reprodução total ou parcial dos trabalhos, desde que seja citada a fonte. Aceita-se permuta com revistas congêneres. Aceitam-se, também, livros para divulgação, elaboração de resenhas e recensões. Toda correspondência, material para publicaçāo (vide normas na terceira capa), assinaturas e permutas devem ser dirigidos ao seguinte destinatário:

PROF. FERNANDO FERRARI FILHO Revista Análise Econômica - Av. João Pessoa, 52 CEP 90040-000 PORTO ALEGRE - RS, BRASIL Telefones: (051) 316-3513 - Fax: (051) 316-3990

Análise Econômica E-mail: rae@ufrgs.br

Ano 22, $n^{\circ} 41$, março, 2004 . Porto Alegre

Faculdade de Ciências Econômicas, UFRGS, 2004

Periodicidade semestral, março e setembro.

Tiragem: 500 exemplares

1. Teoria Econômica - Desenvolvimento Regional -

Economia Agrícola - Pesquisa Teórica e Aplicada -

Periódicos. I. Brasil

Faculdade de Ciências Econômicas,

Universidade Federal do Rio Grande do Sul. 


\title{
A Expanção do Escopo Temático das Negociações Coletivas de Trabalho
}

Carlos Henrique Horn *

Resumo: A partir de fins da década de 1970, as negociações coletivas de trabalho adquiriram uma importância para a regulação da relação de emprego e das relações entre sindicatos de trabalhadores, empresas e sindicatos de empresas no Brasil que não haviam apreciado até então. Um dos indicadores desta maior importância regulatória das negociações coletivas reside exatamente na ampla expansão de seu escopo temático. Neste artigo, examino o alargamento do escopo temático dos acordos coletivos em 17 unidades de negociação na indústria de transformação do Rio Grande do Sul entre 1978 e 1995.

Palavras-Chave: Negociaçōes coletivas de trabalho; Sindicatos; Relações de Trabalho.

\begin{abstract}
Collective bargaining in Brazil has been on the increase since the late 1970s. An enlargement of the bargaining scope has been suggested as evidence of a greater role collective bargaining has performed in regulating both the employment relationship and the relationship between trade unions, employers and employers' associations. In this article, I address the issue of the enlargement of the bargaining scope in 17 bargaining units in manufacturing in the Metropolitan Area of Porto Alegre between 1978 and 1995.
\end{abstract}

Key-Words: Collective Bargaining; Trade Unions; Industrial Relations.

JEL Classification: J5.

\section{Introdução}

No período entre o final dos anos 1970 e o final dos anos 1980, o sistema brasileiro de relações de trabalho presenciou mudanças relevantes após décadas de continuidade institucional do modelo corporativista estatal de representação de interesses. Dentre estas mudanças, admite-se que as negociações coletivas passaram a de-

\footnotetext{
* Professor do Departamento de Ciências Econômicas e do Programa de Pós-Graduação em Economia da UFRGS. E-mail: horn@ufrgs.br.
} 
sempenhar algum papel de importância na regulação da relação de emprego. Um autor chegou mesmo a afirmar que, no final dos anos 1970, as negociações coletivas "começaram a se recuperar de virtual atrofia” (CÓRDOVA, 1989, p.263). Umm rápido crescimento no número de cláusulas foi observado nos acordos coletivos de trabalho (Vasconcellos, 1983; Brandão, 1991; Horn, 1992; Prado, 1998). Isto também ocorreu nas unidades de negociação da indústria de transformação do Rio Grande do Sul que fornecem a evidência deste artigo ${ }^{1}$.

Neste artigo, examino o conteúdo de acordos coletivos selecionados, concentrando-me no escopo temático desses acordos ${ }^{2}$. O principal propósito é o de investigar a ampliação do escopo temático das negociações coletivas que acompanhou o crescimento no número de cláusulas. A análise divide-se em duas grandes partes. $\mathrm{Na}$ primeira parte, evidencio o crescimento no número de cláusulas e seus padrões de mudança entre 1978 e 1995. Na segunda parte, examino os principais tópicos temáticos por meio dos quais o escopo dos acordos ampliou-se no período.

O exame da distribuição das cláusulas coletivas, segundo seu escopo temático, requer classificá-las previamente com base em um esquema de categorias temáticas das normas aplicáveis às relaçōes de trabalho. Ao desenvolver um tal esquema, tomei por ponto de partida uma distinção tradicional entre normas substantivas e normas de procedimento, que passou a ser adotada nos estudos de regras aplicáveis às relações industriais a partir dos trabalhos de Dunlop e Flanders (WOOD et al., 1975, p.24). Entretanto, dado que esta divisão binária não permite uma descrição detalhada do escopo temático dos acordos, unidades de classificação adicionais foram incorpora-

\footnotetext{
' As unidades de negociação coletiva selecionadas são as seguintes: Alimentação (Porto Alegre), Panificação (Porto Alegre), Metalúrgicos (Canoas), Metalúrgicos (Novo Hamburgo), Metalúrgicos (São Leopoldo), Metalúrgicos (Porto Alegre), Metalúrgicos (Sapiranga), Químicos (Porto Alegre), Fertilizantes (Porto Alegre), Farmacêuticos (Porto Alegre), Gráficos (São Leopoldo), Artefatos de Couro (Novo Hamburgo), Calçados (Novo Hamburgo), Calçados (São Leopoldo), Calçados (Campo Bom), Calçados (Sapiranga), e Têxteis (Porto Alegre). No período 1978-95, estas unidades geraram 287 acordos coletivos em nível de setor de atividade, os quais formam a base de dados dos resultados examinados neste trabalho:

${ }^{2}$ Este artigo consiste, em sua maior parte, do capítulo 4 da tese de doutorado do autor, Collective bargaining in Brazilian manufacturing, 1978-95, que resultou de pesquisa sob a supervisão do Prof. Stephen Wood, e que foi submetida à London School of Economics and Political Science (Universidade de Londres) em janeiro de 2003. Para realizar a pesquisa, o autor contou com o apoio de boisa de estudo do $\mathrm{CNPq}$ - Conselho Nacional de Desenvolvimento Científico e Tecnológico.
} 
das ao esquema, resultando em um esquema de categorias para classificação de cláusulas coletivas em quatro níveis de agregação. A terminologia básica e a estrutura deste esquema de classificação são apresentadas na seção 2 .

Na seção 2, trato ainda de um problema metodológico que surge quando se compara o conteúdo das cláusulas coletivas, quer ao longo do tempo, quer entre acordos de diferentes unidades de negociação. Os acordos coletivos da amostra compõem-se de normas escritas e formalizadas. Ao classificar estas normas segundo seu escopo temático, contudo, um problema de comparabilidade aparece em virtude das diferentes maneiras em que as cláusulas são escritas. A redação de um acordo coletivo de trabalho não segue necessariamente um critério claro e único, que faça com que cada cláusula corresponda a uma norma singular sobre um tópico temático específico. Esta ausência de critério claro faz com que a comparação do escopo temático de diferentes acordos torne-se uma tarefa um tanto problemática, senão que impraticável. Por exemplo, em um determinado acordo uma cláusula pode ser um compósito de várias normas sobre diferentes tópicos temáticos, ao passo que, em outro acordo, estas mesmas normas podem ter sido fracionadas em diferentes cláusulas. Neste caso, poderia parecer que um dos acordos compõe-se de apenas uma regra, enquanto o outro acordo conta com mais de uma regra, ainda que ambos apresentem exatamente o mesmo conteúdo. Uma solução para este problema exige que as normas sejam singularizadas a fim de que cada regra individual corresponda a um tópico temático específico. Cada norma deve ser, então, consistentemente classificada em uma categoria específica, ao longo do tempo e nos diferentes acordos coletivos. A análise do escopo temático dos acordos somente se faz possível a partir do ponto em que as cláusulas coletivas forem rearranjadas e classificadas segundo seu objeto temático.

Uma vez apresentada a metodologia para a classificação das cláusulas coletivas, inicio a análise dos acordos da amostra na seção 3, examinando o grande crescimento no número de cláusulas entre 1978 e 1995. As estatísticas deste crescimento são mostradas, o que permite tratar dos padrōes de mudança no número de cláusulas neste período. $\mathrm{Na}$ seção 4 , trato finalmente do assunto principal deste artigo, o escopo temático dos acordos coletivos. Começo por evidenciar quão restrito era este escopo em fins dos anos 1970. Ex- 
ponho, então, o alargamento do escopo temático até meados dos anos 1990, concluindo com uma descrição dos tópicos mais freqüentemente enfocados nos acordos de 1995. As conclusōes são realçadas na seção 5 .

\section{Metodologia para a classificação das cláusulas dos acordos coletivos de trabalho segundo o escopo temático}

O objetivo desta seção é o de apresentar a terminologia básica e um esquema de classificação de cláusulas coletivas para análise do escopo temático das negociações coletivas de trabalho. Enfrento, ademais, um problema metodológico que surge quando se compara o conteúdo das cláusulas entre diferentes unidades de negociação e ao longo do tempo. Na subseção 2.1, defino norma substantiva e norma de procedimento. Esta distinção primária sobre os tipos de regras aplicáveis às relaçōes de trabalho forma o ponto de partida para se desenvolver um esquema de classificação de cláusulas com o objetivo de se analisar o escopo temático das negociações. Na seção 2.2, apresento este esquema de classificação de cláusulas e proponho um procedimento para se evitar o problema metodológico que aparece na comparação entre cláusulas coletivas em sua redação original.

\subsection{Normas substantivas e normas de procedimento}

As negociações coletivas de trabalho são um processo de determinação de normas. Elas são primariamente concebidas para estipular regras que regulam a relação de emprego. Normas coletivas sobre a relação de emprego consistem de direitos e obrigações a que empregadores e empregados (as partes) devem se submeter. Entretanto, dado que são conduzidas através da interação entre outros agentes sociais que desempenham o papel de negociadores normalmente, sindicatos de trabalhadores e associaçōes patronais (os agentes de negociação) -, as negociações coletivas tratam também das relações entre estes agentes e de seus direitos e obrigações institucionais.

As definições de negociação coletiva usualmente destacam dois grupos de regras principais dos acordos coletivos (WINDMULLER, 
1987, p.3; DEAKIN e MORRIS, 1995, p.3; BAMBER e CÓRDOVA, 1993 , p.371; BURCHILL, 1997, p.99). Uma dicotomia clássica é encontrada na literatura de relações industriais pelo menos desde Dunlop e Flanders. Estes autores, que são considerados os dois mais proeminentes representantes da assimchamada 'escola das normas' (rules school), propuseram uma distinção entre normas substantivas e normas de procedimento (WOOD et al., 1975). Em seu trabalho seminal de 1958, Industrial Relations Systems, Dunlop define a esfera de aplicação das normas substantivas através de uma lista de aspectos da relação de emprego (Wood et al. denominam-na 'definição descritiva'), ao passo que as normas de procedimento se ocupariam do estabelecimento e administração das normas substantivas (DUNLOP, 1993, p.51-52). Já Flanders, em sua discussão teórica sobre as negociações coletivas de trabalho, sugere uma dicotomia similar ao expor que: "Os agentes das negociações coletivas negociam acordos substantivos e de procedimento a fim de regular suas próprias relações de modo distinto da relação de emprego de. seus constituintes" (FLANDERS, 1970, p. 222).

Wood et al. (1975) discutem o papel e a classificação de normas no âmbito da teoria de relações industriais com ênfase nos trabalhos de Dunlop e Flanders. Uma demarcação é apresentada entre normas substantivas e normas de procedimento nos seguintes termos:

Normas substantivas:

- normas que governam ação no sistema de produção (p. 22);

- normas que governam a relação de emprego (p. 24).

Normas de - normas que governam ação no sistema de relações de procedimento: trabalho (p. 22);

- normas que governam o processo de definição de regras ( $\mathrm{p}$. 24).

$\mathrm{Na}$ classificação das cláusulas coletivas segundo seu escopo temático, esta distinção básica entre normas substantivas, que governam a relação de emprego, e normas de procedimento, que governam o processo de elaboração e cumprimento das regras, constitui o primeiro passo.

As normas substantivas, portanto, têm como finalidade regular diretamente a relação de emprego. São regras que governam os postos de trabalho. Assim, as normas substantivas em acordos coletivos aplicam-se a todos os contratos individuais sujeitos aos acor- 
dos. A relação entre os empregadores e os empregados deve obedecer ao conjunto de direitos e obrigações estipulado nas cláusulas coletivas. Ao regular os postos de trabalho, as normas substantivas podem definir um amplo conjunto de direitos e obrigações associados a um particular posto de trabalho, compreendendo, por exemplo, regras sobre remuneração, contratação, duração do contrato individual, jornada de trabalho, e rescisão do contrato de trabalho. Mais ainda, as normas substantivas podem mesmo definir que o beneficiário direto final de determinado direito seja outra pessoa que não o empregador ou o empregado, desde que o benefício se encontre fixado em regra vinculada ao posto de trabalho. Um benefício que estabeleça que o empregador deve cobrir as despesas de educação dos filhos dos seus empregados é um exemplo deste caso. A criança torna-se elegivel no exato momento em que um de seus pais passa a ocupar um posto de trabalho regulado por este tipo de norma.

As normas de procedimento, por sua vez, são primeiramente definidas como o negativo das normas substantivas: elas não têm como finalidade regular diretamente a relação de emprego. O que as normas de procedimento fazem é regular indiretamente a relação de emprego ao ajustar o processo de formulação, aplicação e observância das regras, quer estas sejam substantivas ou de procedimento. Por conseguinte, as normas de procedimento versam sobre a relação entre os agentes de negociação e os direitos e obrigações institucionais relativos a seu papel de negociadores. Na maior parte das vezes, as normas de procedimento buscam regulamentar (i) a relação entre os sindicatos de trabalhadores e as associações (ou os sindicatos) de empregadores, quando, por exemplo, definem os procedimentos empregáveis nas rodadas de negociação; e (ii) os direitos e obrigações institucionais de cada agente em sua relação com os demais agentes e as partes, a exemplo do direito dos sindicatos de trabalhadores de convocar reuniões de seus membros nos locais de trabalho para discutir aspectos das negociações coletivas. As normas de procedimento são também empregadas para definir os modos de aplicação e para fazer cumprir os acordos coletivos. São exemplos de cláusulas com esta finalidade as que fixam a duração do acordo coletivo (modo de aplicação) e as que definem sanções a empregadores individuais que se opõem ao cumprimento das regras substantivas (observância). 


\subsection{Esquema de classificação de cláusulas segundo o escopo temático}

Com o intuito de realizar uma análise mais detalhada do escopo temático dos acordos coletivos, há que se ir além da demarcação básica entre normas substantivas e normas de procedimento. Para tanto, um esquema mais compreensivo de classificação de cláusulas segundo seu objeto temático foi desenvolvido com base na gama de tópicos enfocados nos acordos coletivos da amostra. Este esquema de classificação, ademais, tomou por referência os esquemas propostos em DIEESE (1995) e Dunning (1985). Alguns estudos sobre o conteúdo dos acordos coletivos e das normas estatais aplicáveis às relações de trabalho também se mostraram úteis para compor o esquema de classificação (GRUBB e WELLS, 1993; DUNN e WRIGHT, 1994; STOREY, 1980; GREEN, 1994).

A unidade básica do esquema de classificação é o tópico temático da cláusula coletiva. Com a finalidade de classificar as cláusulas segundo as diferentes categorias de tópicos temáticos, todavia, foi necessário reordenar os conteúdos destas cláusulas. Isto porque, como já foi referido na introdução deste artigo, tomar as cláusulas coletivas conforme sua redação e ordem originais acarretaria sérios problemas metodológicos para a análise comparativa do conteúdo dos acordos ao longo do tempo e entre diferentes unidades de negociação. As cláusulas originais não permitem comparar coisa com coisa. Considere o caso hipotético de dois acordos coletivos quaisquer: o acordo A inclui uma cláusula que estipula regras sobre mais de um particular tópico temático, ao passo que estas mesmas regras (idênticos tópicos temáticos e conteúdo normativo) são arranjadas em mais de uma cláusula no acordo $B$. Tal situação poderia acarretar um erro de interpretação quanto à extensão da cobertura temática dos acordos. Não obstante, ambos os acordos estipularem regras idênticas, poder-se-ia deduzir, com base exclusivamente no número de cláusulas, que o acordo $B$ abrange uma maior variedade de tópicos temáticos em virtude de possuir mais cláusulas. $\mathrm{O}$ procedimento analítico correto, neste caso, consistiria em comparar o conteúdo de uma única cláusula no acordo A com o conteúdo de mais de uma cláusula no acordo $\mathrm{B}$.

Por conseguinte, o conteúdo dos acordos coletivos selecionados teve que ser rearranjado, tanto quanto possível, com o intuito de individualizar as regras segundo seu tópico temático específico. 
Em particular, este procedimento buscou evitar que normas sobre diferentes tópicos temáticos permanecessem mescladas em uma mesma cláusula. Dois tipos de ajustamento são de particular interesse. Primeiro, se a cláusula original consistir de um composto de normas sobre diferentes tópicos temáticos, seu conteúdo deve ser separado em tantas normas individuais quantos forem os tópicos temáticos. Para fins de análise, uma norma deve necessariamente corresponder a um tópico temático específico. Segundo, se o conteúdo de mais de uma cláusula corresponder a um mesmo tópico temático, ele deve ser combinado para resultar em uma única cláusula. Como conseqüência deste reordenamento, o número de cláusulas tal como disposto originalmente nos acordos poderá ser diferente, e em quase a totalidade dos casos o é, do número de cláusulas após os ajustes, ainda que o conteúdo normativo do acordo seja exatamente o mesmo antes e após seu reordenamento. Assim, no restante deste estudo, a expressão cláusula referir-se-á às normas de acordos coletivos após o reordenamento de seu conteúdo.

O esquema de classificação de cláusulas segundo o escopo temático compreende quatro níveis de agregação. O primeiro nível, que consiste da sua unidade básica, é o tópico temático da cláusula. Por exemplo, as cláusulas que fixam uma percentagem de reajuste dos salários nominais vinculada ao aumento no custo de vida são classificadas no tópico temático 'reajuste salarial baseado no aumento do custo de vida'. Os tópicos com escopo temático semelhante são reunidos em grupos temáticos, que compreendem o segundo nível de agregação do esquema. Por exemplo, todas as cláusulas sobre reajuste de salários nominais são reunidas em um grupo temático de mesmo nome, compreendendo, dentre outros, os seguintes tópicos: reajuste salarial baseado no aumento do custo de vida, salários mínimos e reajuste salarial do novo empregado. O terceiro nível de agregação reúne os grupos temáticos semelhantes em temas. O tema intitulado 'remuneração', por exemplo, abrange todos os tópicos e grupos que se referem a este aspecto da relação de emprego. Por fim, no quarto nível de agregação, os temas dividem-se em normas substantivas e normas de procedimento, segundo a definição da subseção anterior.

O esquema completo de classificação compreende 163 tópicos temáticos, 32 grupos temáticos e 13 temas. Cada tópico temático foi definido com base na condição de que pelo menos uma cláusula 
dos acordos coletivos selecionados tratasse do assunto do tópico. Logo, o próprio esquema de classificação oferece uma noção preliminar sobre o escopo temático dos acordos. Por exemplo, o fato de o esquema possuir 46 tópicos temáticos sobre remuneração indica a maior freqüência de cláusulas classificadas neste tema do que, digamos, cláusulas classificadas nos temas treinamento ou trabalho temporário, que juntos resultaram em apenas três tópicos temáticos. O quadro 1 apresenta as categorias do esquema de classificação.

\section{Quadro 1: Esquema de classificação de cláusulas de acordos coletivos de trabalho segundo o escopo temático}

\begin{tabular}{|c|c|}
\hline \multicolumn{2}{|r|}{ NORMAS SUBSTANTIVAS } \\
\hline \multicolumn{2}{|r|}{ Tema I - REMUNERACÃOA } \\
\hline \multirow{11}{*}{$\begin{array}{l}\text { Grupo } 0101 \\
\text { Recjuste dos salário nominais }\end{array}$} & - Requuste dos salários nominais baseado no aumento do custo de vida \\
\hline & - Requste dos salários nominais baseado no aumento da produtividade ou outro "aumento real") \\
\hline & $\begin{array}{l}\text { - Requiste dos salórios nominais de empregado admitido após a último data-base de revisōo de dissídio } \\
\text { (empegado novol }\end{array}$ \\
\hline & - Polífica de reciuste salorial \\
\hline & - Normas complementares sobre reajuste dos salários nominais \\
\hline & - Salários mínimos \\
\hline & - Polífica de reajuste de salários mínimos \\
\hline & - Salários mínimos: casos especiais \\
\hline & - Salário de substituição \\
\hline & - Salário de admissão \\
\hline & - Discriminæção salarial \\
\hline \multirow{11}{*}{$\begin{array}{l}\text { Gupo } 0102 \\
\text { Procedimentos administrativos } \\
\text { sobre remuneração }\end{array}$} & - Data normal de pagamento \\
\hline & $\begin{array}{l}\text { - Data de pagamento da diferença de salário decorrente do } \\
\text { acordo coletivo }\end{array}$ \\
\hline & - Forma de pagamento \\
\hline & - Gritérios de cálculo da remuneração \\
\hline & - Adiontamento de solório \\
\hline & - Recibos e demonstrativos de pagamento \\
\hline & - Dedux̧öes \\
\hline & - Gritério de cáculo da remuneração em casos es peciais \\
\hline & - Atestado médico para garontia de remunoração \\
\hline & - Atrasos \\
\hline & - Garantia de salários em caso de interrupscão da jornada \\
\hline \multirow{6}{*}{$\begin{array}{l}\text { Gupo } 0103 \\
\text { Horas extras }\end{array}$} & - Taxa geral \\
\hline & - Domingos, feriados, descanso semanal \\
\hline & $\begin{array}{l}\text { Feriados nos sábadas e similares sob regime de compensação } \\
\text { de jornada }\end{array}$ \\
\hline & - Gozo de férias \\
\hline & $\begin{array}{l}\text { - Chamada para serviços en caráter de emergência thora de } \\
\text { sobreavisol }\end{array}$ \\
\hline & - Descanso semanal sob regime de compensação de jornada \\
\hline
\end{tabular}




\begin{tabular}{|c|c|}
\hline \multicolumn{2}{|r|}{ NORMAS SUBSTANTIVAS } \\
\hline \multicolumn{2}{|r|}{ Tema l - REMUNERAÇÃO } \\
\hline \multirow{7}{*}{$\begin{array}{l}\text { Gupo } 0104 \\
\text { Adicionais e gratificações de salário lexclusive horas extras) }\end{array}$} & - Adicional nofur no \\
\hline & - Adicional por tempo de serviço \\
\hline & - Antecipação de 13\% salário \\
\hline & - Pagamento de $13^{\circ}$ salário em casos especiais \\
\hline & - Adicional de insalubridade \\
\hline & - Gratificação de lunção especial \\
\hline & - Remuneração extr coordinária \\
\hline \multirow{11}{*}{$\begin{array}{l}\text { Gupo } 0105 \\
\text { Solários indiretos a auxilios }\end{array}$} & - Alimentação \\
\hline & - Transporte \\
\hline & - Educaçõo \\
\hline & - Salário-oducação \\
\hline & - Creche \\
\hline & - Complementação do auxílio-doença \\
\hline & - Aposentadoria \\
\hline & - Auxilio funeral \\
\hline & - Cesła bớsica \\
\hline & - Casamento \\
\hline & - Normas complementares sobre salários indiretos \\
\hline \multicolumn{2}{|c|}{ Tema 2 - JORNADA OE TRABACHO } \\
\hline \multirow{8}{*}{$\begin{array}{l}\text { Gupo } 0201 \\
\text { bornado normal da trobalito }\end{array}$} & - Lornada semanal normal máxima \\
\hline & - Distribuição da ja nada semanal normal máxima: Regime de componsoçẫo de horas \\
\hline & - Intervalos par a repouso e alimentaçäo \\
\hline & - Horório de ingrasso o soído \\
\hline & - Registro de ingresso e saida \\
\hline & - Tempo de deslocamento até o local de trabatho \\
\hline & - brnarda de purnos \\
\hline & - Insolubridade: Regima de compensoçço de horas \\
\hline \multirow{2}{*}{$\begin{array}{l}\text { Grupo } 0203 \\
\text { binado de mutheres }\end{array}$} & - Lornoda extroordinária: Regime de compensação da horas \\
\hline & - Amamentą̧,ōo \\
\hline \multirow{2}{*}{$\begin{array}{l}\text { Grupo } 0204 \\
\text { bornoda de menores }\end{array}$} & - Sornada extroordinária: Regime de compensação da horas \\
\hline & \\
\hline \multirow{3}{*}{$\begin{array}{l}\text { Grupo } 0209 \\
\text { Normas especiais sobre jornada de trabalho }\end{array}$} & - Redução ou suprassão de jornada \\
\hline & - Jornoda de estudantes \\
\hline & - Extensão de feriodos: Regime de compensoscäo do horas \\
\hline \multicolumn{2}{|c|}{ Tema 03 - FERIAS E LICENCAS REMUNERADAS } \\
\hline \multirow{10}{*}{$\begin{array}{l}\text { Gupo } 0301 \\
\text { Férias }\end{array}$} & - Data de pagamento \\
\hline & - Data de início do perfodo do gozo \\
\hline & - Parcelamento do períado de gozo \\
\hline & - Comunicações a empregados \\
\hline & - Conversão em pecúnía \\
\hline & - Empregado com período aquisitivo incompleto: Antecipação do período de gozo \\
\hline & - Empregado com período aquisitivo incompleto: Pagomento \\
\hline & - Empregado acidentado ou afastado com auxíio-doença \\
\hline & - Féricis colelivas \\
\hline & - Normas complementares sobre lérias \\
\hline
\end{tabular}




\begin{tabular}{|c|c|}
\hline \multicolumn{2}{|c|}{ Tema 03 - F́RIAS E LLCENCAS REMUNERADAS } \\
\hline \multirow{7}{*}{$\begin{array}{l}\text { Gupo } 0302 \\
\text { Licença remuner ada }\end{array}$} & - Mulheres: Nascimento de fillho \\
\hline & - Homens: Nascimento de filho \\
\hline & - Aborto \\
\hline & - Casamento \\
\hline & - Falocimento de parentes \\
\hline & - Consulta médica de parentes \\
\hline & - Hospitalização de parentes \\
\hline \multirow{6}{*}{$\begin{array}{l}\text { Gupo } 0302 \\
\text { Licença remuner ada }\end{array}$} & - Daação de sangue \\
\hline & - Atuação como testemunho em processo judicial \\
\hline & - Recebimento do PIS \\
\hline & - Estudante \\
\hline & - Dónça do parentes \\
\hline & - Normas complementares sobre licença remunerada \\
\hline \multicolumn{2}{|c|}{ Tema 04 - RECRUTAMENTO E CONTRATO DE TRABALHO } \\
\hline \multirow{4}{*}{$\begin{array}{l}\text { Gupo } 0401 \\
\text { Recrutamento, promoç̃o e Transfer ências }\end{array}$} & - Testes para recrutamento \\
\hline & - Transferênkia de local de trabalho \\
\hline & - Recrutamento e promoçăo \\
\hline & - Planos de cargos e salários \\
\hline \multirow{3}{*}{$\begin{array}{l}\text { Grupo } 0402 \\
\text { Poríodo de experiência }\end{array}$} & - Pré-requisitos \\
\hline & - Dur ação do período de experiência \\
\hline & - Excoçöes \\
\hline \multirow{4}{*}{$\begin{array}{l}\text { Gupo } 0403 \\
\text { Registros o comunicaçōes }\end{array}$} & - Obrigação de registrar na carteira de trabalho \\
\hline & - Proibição de registrar na carteira de trabahtho \\
\hline & - Obrigação de fornecer documentos \\
\hline & - Obrigação de comuniçação/informação \\
\hline \multirow[t]{5}{*}{$\begin{array}{l}\text { Guppo } 0404 \\
\text { Licença näo-remunerada }\end{array}$} & - Consulta médica de parentes \\
\hline & - Hospitalização de parentes \\
\hline & - Recebimento do PIS \\
\hline & - Busca de documentos \\
\hline & - CIPA \\
\hline \multicolumn{2}{|c|}{ Tema 05 - SEGURANCA NO EMPREGO E RESCISÃO DO CONTRATO DE TRABALHO } \\
\hline \multirow{4}{*}{$\begin{array}{l}\text { Gupo } 0501 \\
\text { Segurança no emprego }\end{array}$} & - Gravidez \\
\hline & - Serviço militar \\
\hline & - Acidente e auxilio doença \\
\hline & - Emprogado próximo da aposentadoria \\
\hline \multirow{4}{*}{$\begin{array}{l}\text { Gupo } 0502 \\
\text { Procedimentos administrativos para recisão de contrato }\end{array}$} & - Assistência do sindicalo \\
\hline & - Data-limite para pagamentos após rescisão do contrato de trabalho \\
\hline & - Cálculo de pagamentos em rescisão do contrato de trabalho \\
\hline & - Documentos e comunicação \\
\hline
\end{tabular}




\begin{tabular}{|c|c|}
\hline \multicolumn{2}{|c|}{ Temo 05 - SEGURANCA NO EMPREGO E RESUSÃO DO CONTRATO DE RRABALHO } \\
\hline \multirow{6}{*}{$\begin{array}{l}\text { Gupo } 0503 \\
\text { Aviso-prévio }\end{array}$} & - Período de aviso-prévio \\
\hline & - Rescisão antes de se completar o periodo de avisopprévio \\
\hline & - Normas especicis \\
\hline & - Tempo para procura de novo emprego \\
\hline & - Indenização em rescisão do contrato de trabolho \\
\hline & - FGTS \\
\hline \multicolumn{2}{|r|}{ Tema 06 - TRABALHO TEMPORÁRIO } \\
\hline \multirow{2}{*}{$\begin{array}{l}\text { Grupo } 0601 \\
\text { Contrato de trabalho com prazo deter minado }\end{array}$} & - Pré-requisitos \\
\hline & \\
\hline \multirow{3}{*}{$\begin{array}{l}\text { Grupo } 0701 \\
\text { Treinamento }\end{array}$} & Tema 07 - TREINAMENTO \\
\hline & Treinamento \\
\hline & Novas tecnologias: Treinamento e reocupação \\
\hline \multicolumn{2}{|c|}{\begin{tabular}{|c|} 
Tema $08 \cdot$ CONDCÓES DE TRABALHO \\
\end{tabular}} \\
\hline \multirow{5}{*}{$\begin{array}{l}\text { Gupo } 0801 \\
\text { Ambiente de trabalho e bem-estar }\end{array}$} & Uniforme \\
\hline & - Equipamentos e ferramentas \\
\hline & - Instalacōes e facilidades \\
\hline & - Mulheres \\
\hline & - Dever de cuidar \\
\hline \multirow{4}{*}{$\begin{array}{l}\text { Grupo } 0802 \\
\text { Segurança do trabalho }\end{array}$} & - Equipamento de proteção \\
\hline & - Informação e treinamento \\
\hline & - Profissionais de segurança \\
\hline & - Medidas preventivas \\
\hline \multirow{7}{*}{$\begin{array}{l}\text { Grupo } 0803 \\
\text { Saúde }\end{array}$} & - Condicōes gerais \\
\hline & - Primeiros socorros \\
\hline & - Exames médicos \\
\hline & AIDS \\
\hline & - Plano de assistência à saúde \\
\hline & - Mulheres \\
\hline & - Informação e treinamento \\
\hline \multicolumn{2}{|r|}{ NORMAS DE PROCEDIMENTO } \\
\hline \multicolumn{2}{|r|}{ Tema 09 - RELACÓES SINDRCAIS } \\
\hline \multirow{2}{*}{$\begin{array}{l}\text { Gupo } 0901 \\
\text { Focilidades co sindicato de empregados }\end{array}$} & - Acesso go local de trabalho \\
\hline & - Liberacão de dirigente sindical \\
\hline $\begin{array}{l}\text { Gupo } 0902 \\
\text { lnformacõo e comunicacão }\end{array}$ & - Informação e comunicação \\
\hline \multirow{4}{*}{$\begin{array}{l}\text { Grupo } 0903 \\
\text { Finanças do sindicato de empregados }\end{array}$} & - Desconto/contribuição as sistencial \\
\hline & - Deduxão de contribuição sindical \\
\hline & - Imposto sindical \\
\hline & - Contribuição de empregadores a sindicato de empregados \\
\hline $\begin{array}{l}\text { Grupo } 0905 \\
\text { Delegados sindiccis }\end{array}$ & - Delegados sindicais \\
\hline \multicolumn{2}{|c|}{ Tema 10 - PROCEDIMENTOS DE NEGOCIACÃO E DE RESOLUCÃO DE CONFLITOS } \\
\hline \multirow{8}{*}{$\begin{array}{l}\text { Grupo } 1001 \\
\text { Procedimentos de negociação }\end{array}$} & - Rodadas de negociação dur ante a vigência do acordo coletivo \\
\hline & - Renegociaccão de cláusulas durante a vigência do acordo coletivo \\
\hline & - Segur anca no emprego de dirigente sindical e de membro da comissão de negociações \\
\hline & - Extensão do períado de vigência do acordo coletivo \\
\hline & - Declaraçōes de intenção \\
\hline & - Registro do acordo coletivo na Delegacia Regional do Trabalho \\
\hline & - Normas de negociacão teferentes a assuntos da CIPA \\
\hline & - Comissões de negociação \\
\hline \multirow{3}{*}{$\begin{array}{l}\text { Grupo } 1002 \\
\text { Procedimentos de resolução de conflitos }\end{array}$} & - Cumprimento do acordo coletivo \\
\hline & - Justica do Trabalho \\
\hline & - Greve e acöes semelhantes \\
\hline
\end{tabular}




\begin{tabular}{|c|c|}
\hline & \\
\hline Normas complementores sobre o acordo coletivo & - Partes \\
\hline & - Database \\
\hline & - Período de vigência \\
\hline & - Cobertura do acordo: calegorias e base territorial \\
\hline \multicolumn{2}{|r|}{ Tema 12 - SANCÕES } \\
\hline $\begin{array}{l}\text { Gupo } 1201 \\
\text { Sancöes }\end{array}$ & - Atraso na transferência de taxas e contribuiçōes sindicais \\
\hline & Descumprimento de cláusula (gerall) \\
\hline & - Atraso no pagamento de salários \\
\hline & - Falta de registro na carteira de trabalho. \\
\hline & - Atraso no pagamento de verbas rescisórias \\
\hline & - Falta de divulgaçäo do acordo coletivo no local de trabalho \\
\hline & - Não-pagamento nos termos do acordo coletivo \\
\hline \multicolumn{2}{|c|}{ Tema 13 - SINDICATOS DE EMPREGADORES } \\
\hline $\begin{array}{l}\text { Grupo } 1301 \\
\text { Finanças de sindicatos de Empregodores }\end{array}$ & Finanças de sindicatos de empregadores \\
\hline
\end{tabular}

Nesta seção, apresentei a terminologia básica e um esquema de classificação de cláusulas coletivas com o objetivo de permitir a análise do escopo temático dos acordos coletivos da amostra. Antes de proceder com esta análise, entretanto, estatísticas sobre o rápido crescimento no número de cláusulas dos acordos da amostra, entre 1978 e 1995, são mostradas na seção 3. Este crescimento foi acompanhado por um alargamento do escopo temático, como será evidenciado na seção 3 .

\section{0 crescimento no número de cláusulas}

Um rápido crescimento no número de cláusulas dos acordos coletivos a partir de fins dos anos 1970 tem sido registrado em vários estudos sobre negociações coletivas de trabalho no Brasil (VASCONCELLOS, 1983; BRANDÃO, 1991; PRADO, 1998). Ao analisar as negociações coletivas do setor bancário, constatei que o número de cláusulas dos acordos referentes à base de Porto Alegre permaneceu virtualmente constante entre 1962 e 1978, oscilando entre 12 e 14 cláusulas. Após alguns anos de forte crescimento, todavia, este número havia mais do que triplicado, chegando a 47 cláusulas em 1988 (HORN, 1992). Este considerável aumento no número de cláusulas sugere um fortalecimento das negociações coletivas como método de regulação da relação de emprego no Brasil a partir do final da década dos 1970. 
De modo similar ao que tem sido registrado para outras unidades de negociação, o número de cláusulas nos acordos coletivos selecionados da indústria de transformação do Rio Grande do Sul cresceu vigorosamente a partir do final dos anos 1970. Em 1978, estes acordos coletivos compreendiam apenas 8,2 cláusulas em média. Em 1995, este número tinha se multiplicado por quase oito vezes, alcançando 64,1 cláusulas. A figura 1 mostra o número médio de cláusulas entre 1978 e 1995.

Figura 1: Número médio de cláusulas, em acordos coletivos selecionados da indústria de transformação do Rio Grande do Sul, 1978-95

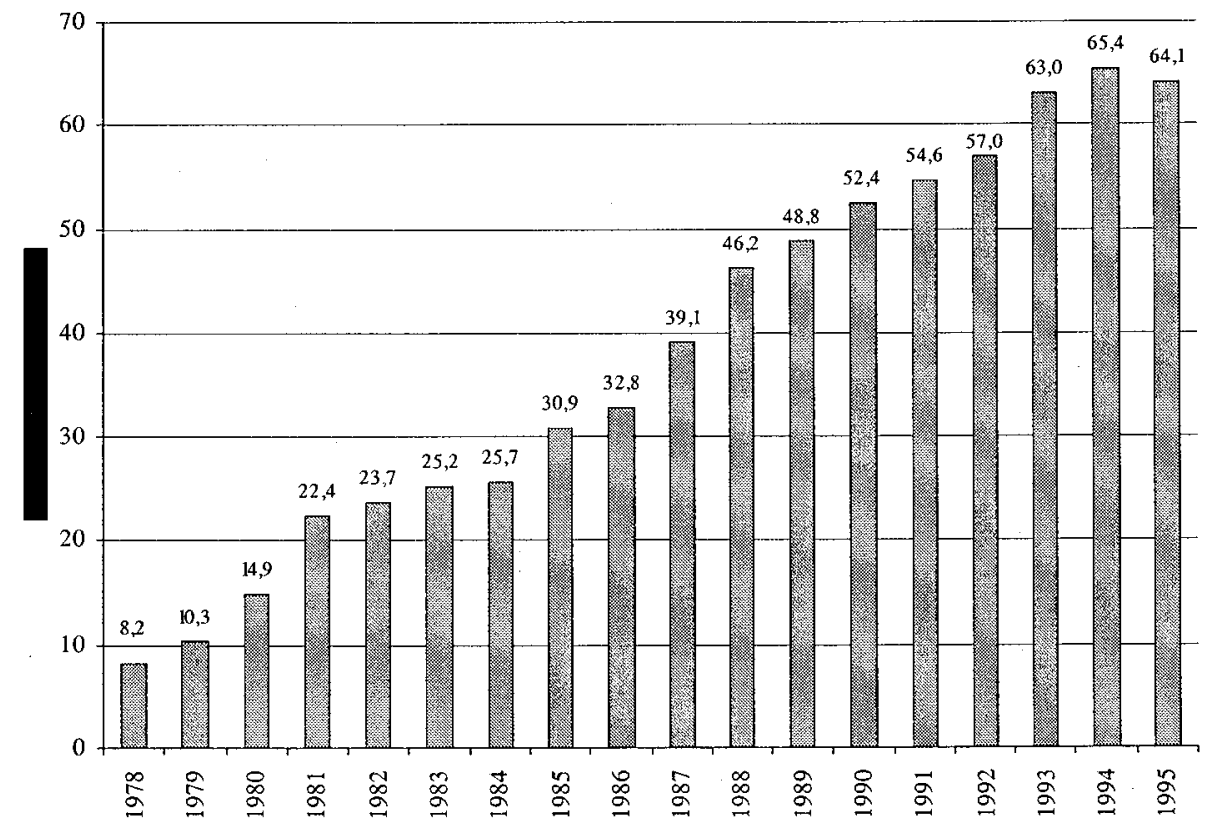

O reduzido número de cláusulas em 1978 indica que as negociaçôes coletivas ainda não tinham assumido, naquele ano, um papel relevante como método de regulação da relação de emprego, em contraste com a extensa legislação estatal. Os dados sobre a distribuição dos acordos por número de cláusulas reforçam esta conclusão. Primeiro, onze acordos coletivos tinham um número de cláusulas menor do que a média ( 8,2 cláusulas). Segundo, apenas um acordo coletivo possuía mais do que 11 cláusulas, alcançando 17 cláusulas. Se for notado que, em 1978, quase quatro décadas haviam se 
passado desde a consolidação de um arcabouço legal para as negociações coletivas na CLT, há que se entender que este crescimento no número de cláusulas a partir do final dos anos 1970 constituiu um sinal de mudança no sistema de relações de trabalho.

$\mathrm{O}$ crescimento no número de cláusulas não foi absolutamente linear. Períodos de crescimento mais rápido alternaram-se com períodos de crescimento mais lento entre 1978 e 1995. Ao se tomar a média ( 3,1 cláusulas) e a mediana ( 2,5 cláusulas) da distribuição da variação anual no número médio de cláusulas como padrão de comparação, observam-se dois períodos de crescimento rápido e dois períodos de crescimento lento no número de cláusulas. Estes períodos estão caracterizados nos parágrafos que seguem.

Período 1978-81

O primeiro período, que se estendeu de 1978 a 1981, coincidiu com um momento de virada no sindicalismo brasileiro. Os sindicatos de trabalhadores passaram a pressionar os empregadores a negociar contratos coletivos em um contexto econômico favorável, caracterizado por uma baixa taxa de desemprego, e em um cenário político menos autoritário. O número médio de cláusulas nos acordos da amostra cresceu de 8,2 para 22,4 cláusulas. A taxa de variação aumentou ano a ano, atingindo 7,5 cláusulas em 1981. A tabela 1 mostra as estatísticas básicas deste período.

Tabela I: Estatísticas sobre o número de cláusulas, em acordos coletivos selecionados da indústria de transformação do Rio Grande do Sul, 1978-81

\begin{tabular}{|c|c|c|c|c|c|c|c|c|c|c|}
\hline \multirow[t]{3}{*}{ Ano } & \multirow{3}{*}{ 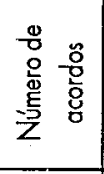 } & \multicolumn{3}{|c|}{ Número de cláusulas } & \multicolumn{6}{|c|}{ Variação anual no número de cláusulas } \\
\hline & & \multirow[t]{2}{*}{ Média } & \multicolumn{2}{|c|}{ Intervalo } & \multirow[t]{2}{*}{ Média } & \multicolumn{2}{|c|}{ Intervalo' } & \multicolumn{3}{|c|}{$\begin{array}{l}\text { Número de acordos sob } \\
\text { condição de que }^{1}\end{array}$} \\
\hline & & & Min & Max & & Min & Max & $\Delta N>0$ & $\Delta \mathrm{N}=0$ & $\Delta \mathrm{N}<0$ \\
\hline 1978 & 17 & 8,2 & 5 & 17 & - & • & n & - & . & - \\
\hline 1979 & 16 & 10,3 & 6 & 18 & 2,1 & -4 & 8 & 12 & 3 & 2 \\
\hline 1980 & 16 & 14,9 & 7 & 36 & 4,6 & 0 & 18 & 15 & 2 & 0 \\
\hline 1981 & 15 & 22,4 & 9 & 42 & 7,5 & -1 & 19 & 15 & 1 & 1 \\
\hline Média & 16 & 14,0 & 7,3 & 32,0 & 4,5 & 0 & 15,0 & 14,0 & 2,0 & 1,0 \\
\hline
\end{tabular}

${ }^{1}$ A fim de se encontrarem estes indicadores nas tabelas 1 a 4 , um valor foi imputado para 0 número de cláusulas nos casos de unidades de negociação que não chegaram a um acordo coletivo (apenas 19 em 306 casos entre 1978 e 1995). Em um ano qualquer, este valor foi calculado como o ponto médio entre o número de cláusulas no ano imediatamente anterior e no ano imediatamente posterior. 
Uma variação negativa no número de cláusulas em acordos individuais foi registrada em apenas três casos no período. $O$ caso dos metalúrgicos de São Leopoldo, com perda líquida de quatro cláusulas em 1979, é particularmente interessante. Esta variação resultou de uma supressão de oito cláusulas, sendo a maioria sobre relações sindicais e procedimentos de resolução de conflitos, combinada a uma adição de quatro novas cláusulas substantivas sobre remuneração e jornada de trabalho. Dentre as cláusulas suprimidas, encontrava-se uma norma ímpar que estipulava que os empregadores individuais deveriam realizar contribuições financeiras ao sindicato dos trabalhadores. O caso dos metalúrgicos de São Leopoldo ilustra um movimento cujo sentido era o de ajustar os tópicos de negociação a uma nova era.

Como conseqüência de três anos sucessivos de crescimento no número de cláusulas, o intervalo entre o acordo com o menor número de cláusulas e o acordo com o maior número de cláusulas passou de 5-17 cláusulas, em 1978, para 9-42 cláusulas em 1981. Ainda em média, a variação anual no número de cláusulas foi positiva em 14 dentre 17 acordos, enquanto a variação foi negativa em apenas um acordo.

\section{Período 1982-84}

Em 1982, entretanto, perdeu ímpeto a tendência ao crescimento no número de cláusulas. Um período de menor variação no número de cláusulas substituiu o ritmo vigoroso de aumento antes observado, estendendo-se de 1982 a 1984. Durante este período, a taxa de crescimento médio no número de cláusulas recuou para 1,1 cláusula por ano. Além disso, uma proporção maior dos acordos evidenciou variação negativa no montante de cláusulas em pelo menos um dos anos do período $(17,6 \%)$. O crescimento máximo no número de cláusulas em um acordo individual também se reduziu, para 8,3 cláusulas em média contra 15,0 cláusulas registrado no período anterior. A tabela 2 apresenta as estatísticas básicas para o período 1982-84. 
Tabela 2: Estatísticas sobre o número de cláusulas, em acordos coletivos selecionados da indústria de transformação do Rio Grande do Sul, 1982-84

\begin{tabular}{|c|c|c|c|c|c|c|c|c|c|c|}
\hline \multirow[t]{3}{*}{ Ano } & \multirow{3}{*}{ 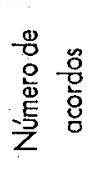 } & \multicolumn{3}{|c|}{ Número de cláusulas } & \multicolumn{6}{|c|}{ Variação anual no número de cláusulas } \\
\hline & & \multirow[t]{2}{*}{ Média } & \multicolumn{2}{|c|}{ Intervalo } & \multirow[t]{2}{*}{ Média } & \multicolumn{2}{|c|}{ Intervalo } & \multicolumn{3}{|c|}{$\begin{array}{c}\text { Número de acordos sob } \\
\text { condição de que }\end{array}$} \\
\hline & & & $\operatorname{Min}$ & $\operatorname{Max}$ & & $\operatorname{Min}$ & $\operatorname{Max}$ & $\Delta N>0$ & $\Delta N=0$ & $\Delta N<0$ \\
\hline 1982 & 17 & 23,7 & 11 & 42 & 1,3 & -3 & 10 & 12 & 2 & 3 \\
\hline 1983 & 17 & 25,2 & 12 & 44 & 1,5 & -1 & 6 & 11 & 5 & 1 \\
\hline 1984 & 16 & 25,7 & 11 & 46 & 0,5 & -2 & 9 & 9 & 3 & 5 \\
\hline Média & 16,7 & 24,9 & 11,3 & $\begin{array}{r}44 \\
4\end{array}$ & 1,1 & $-2,0$ & $\overline{8,3}$ & 10,7 & 3,3 & 3,0 \\
\hline
\end{tabular}

\section{Período 1985-88}

Em meados dos anos 1980, registrou-se um segundo ciclo de rápido crescimento no número de cláusulas nos acordos coletivos da amostra. A variação média anual no número de cláusulas por acordo elevou-se a 5,1 cláusulas entre 1985 e 1988, bastante superior à constatada no período precedente (1,1 cláusula) e também maior do que a média para todo o período 1978-95 (3,1 cláusulas). O crescimento máximo no número de cláusulas em um acordo individual chegou a 20,7 cláusulas, em média, ao passo que a proporção de casos em que houve redução no número de cláusulas caiu para $11,8 \%$ (apenas oito em 68 acordos no período completo). A tabela 3 mostra as estatísticas básicas do período 1985-88.

Tabela 3: Estatísticas sobre o número de cláusulas, em acordos coletivos selecionados da indústria de transformação do Rio Grande do Sul, $1985-88$

\begin{tabular}{|c|c|c|c|c|c|c|c|c|c|c|}
\hline \multirow[t]{3}{*}{ Ano } & \multirow{3}{*}{ 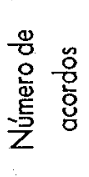 } & \multicolumn{3}{|c|}{ Número de cláusulas } & \multicolumn{6}{|c|}{ Variação anual no número de cláusulas } \\
\hline & & \multirow[t]{2}{*}{ Média } & \multicolumn{2}{|c|}{ Intervalo } & \multirow[t]{2}{*}{ Média } & \multicolumn{2}{|c|}{ Intervalo } & \multicolumn{3}{|c|}{$\begin{array}{l}\text { Número de acordos sob } \\
\text { condição de que }\end{array}$} \\
\hline & & & Min & Max & & Min & $\operatorname{Max}$ & $\Delta N>0$ & $\Delta N=0$ & $\Delta N<0$ \\
\hline 1985 & 17 & 30,9 & 14 & 51 & 5.2 & in & 14 & 16 & 1 & 0 \\
\hline 1986 & 15 & 32,8 & 22 & 55 & 1.9 & -6 & 20 & 10 & 3 & 4 \\
\hline 1987 & 17 & 391 & 21 & 60 & 6.3 & -2 & 24 & 13 & 2 & ? \\
\hline 1988 & 17 & 46,2 & 23 & 79 & 7.1 & .2 & 25 & 14 & 1 & 2 \\
\hline Média & 16,5 & 37,2 & 20,0 & 61,2 & 5 & $-2,5$ & 20,7 & 13,3 & 1,7 & 2,0 \\
\hline
\end{tabular}




\section{Período 1989-95}

O quarto e último período iniciou-se em 1989. Entre este ano e 1995, o crescimento no número médio de cláusulas desacelerou para 2,5 cláusulas por ano. A variação no número médio de cláusulas permaneceu abaixo da média do período 1978-95 em todos os anos, à exceção de 1993. O crescimento máximo no número de cláusulas em um acordo individual recuou para 14,1 cláusulas, em média, enquanto a proporção de casos em que houve redução no número de cláusulas elevou-se para um dentre quatro acordos. A tabela 4 mostra as estatísticas básicas do período 1989-95.

Tabela 4: Estatísticas sobre o número de cláusulas, em acordos coletivos selecionados da indústria de transformação do Rio Grande do Sul, 1989-95

\begin{tabular}{|c|c|c|c|c|c|c|c|c|c|c|}
\hline \multirow[t]{3}{*}{ Ano } & \multirow{3}{*}{ 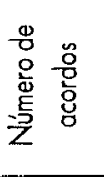 } & \multicolumn{3}{|c|}{ Número de cláusulas } & \multicolumn{6}{|c|}{ Variação anual no número de cláusulas } \\
\hline & & \multirow[t]{2}{*}{ Média } & \multicolumn{2}{|c|}{ Intervalo } & \multirow[t]{2}{*}{ Média } & \multicolumn{2}{|c|}{ Intervalo } & \multicolumn{3}{|c|}{$\begin{array}{l}\text { Número de acordos sob } \\
\text { condição de que }\end{array}$} \\
\hline & & & Min & $\operatorname{Max}$ & & Min & Max & $\Delta \mathrm{N}>0$ & $\Delta \mathrm{N}=0$ & $\Delta \mathrm{N}<0$ \\
\hline 1989 & 17 & 48,8 & 24 & 74 & 2.6 & -5 & 18 & 10 & 1 & 6 \\
\hline 1990 & 16 & 52,4 & 26 & 78 & 3.6 & -10 & 11 & 12 & 2 & 3 \\
\hline 1991 & 16 & 54,6 & 29 & 93 & 2.2 & -9 & 19 & 12 & 2 & 3 \\
\hline 1992 & 16 & 57,0 & 27 & 93 & 24 & -4 & 11 & 10 & 3 & 4 \\
\hline 1993 & 15 & 63,0 & 29 & 86 & 6.0 & 6 & 26 & 13 & 1 & 3 \\
\hline 1994 & 12 & 65,4 & 31 & 87 & 2.4 & -4 & 5 & 7 & 5 & 5 \\
\hline 1995 & 15 & 64,1 & 36 & 91 & -1.4 & -5 & 9 & 9 & 3 & 5 \\
\hline Média & 15,3 & 57,9 & 28,8 & 86,0 & 2,5 & $-6,1$ & 14,1 & 10,4 & 2,4 & 4,2 \\
\hline
\end{tabular}

Entre 1989 e 1992, e mais tarde em 1994, a variação anual no número médio de cláusulas apresentou pequeno desvio em relação à média do período 1989-95 (2,5 cláusulas). Os resultados para 1993 e 1995, entretanto, discreparam deste padrão. Em 1993, o número médio de cláusulas cresceu 6,0 cláusulas. Este resultado pode ser considerado como um evento excepcional durante um período de crescimento mais vagaroso no número de cláusulas. Já em 1995, uma redução no número médio de cláusulas foi observada pela primeira vez desde 1979.

Entre 1978 e 1995, o número médio de cláusulas nos acordos coletivos da amostra multiplicou-se por quase oito vezes. Partindo de uma inexpressiva base de 8,2 cláusulas, na média de 1978, estes acordos coletivos alcançaram 64,1 cláusulas na média de 1995. Em 
conseqüência, numerosos novos tópicos temáticos foram incorporados nas negociações coletivas de trabalho. Esta expansão do escopo temático das negociações é analisada na seção 4.

\section{A expansão do escopo temático dos acordos coletivos}

Nesta seção, analiso o escopo temático dos acordos coletivos da amostra. Na subseção 4.1, mostro a pouca diversidade do escopo temático dos acordos coletivos de 1978. O número limitado de tópicos que caracterizava os acordos ao final dos anos 1970 constitui a base a partir da qual o escopo temático das negociações coletivas ampliou-se até meados dos anos 1990. Na subseção 4.2, analiso a expansão do escopo temático dos acordos coletivos da amostra. Finalmente, na subseção 4.3, registro o escopo das negociaçōes coletivas em 1995, que resultou da expansão observada nos anos anteriores.

\subsection{0 acordo coletivo típico de 1978}

Em 1978, os acordos coletivos selecionados da indústria de transformação do Rio Grande do Sul compreendiam 8,2 cláusulas em média, variando de cinco cláusulas (Têxteis/Porto Alegre e Couros e Peles/Novo Hamburgo) a 17 cláusulas (Metalúrgicos/São Leopoldo). Um inventário completo dos assuntos cobertos pelos acordos coletivos abrangia não mais do que 29 tópicos temáticos. Isto representa apenas $17,8 \%$ do conjunto completo dos tópicos temáticos que vieram a ser abordados nos acordos coletivos pelo menos uma vez entre 1978 e 1995. O quadro 2 mostra os tópicos temáticos cobertos por pelo menos um acordo coletivo da amostra em 1978. Os tópicos estão agrupados por temas.

O número de tópicos temáticos cobertos por um conjunto representativo de acordos coletivos, todavia, era bem menor do que o total de 29 tópicos. Havia apenas seis tópicos temáticos negociados em pelo menos 14 das 17 unidades de negociação. Este grupo de tópicos de alta freqüência compreendia cláusulas sobre o reajuste de salários nominais baseado no aumento do custo de vida (reajuste geral e reajuste de empregado admitido após a última data-base de revisão de dissídio), a distribuição da jornada semanal normal máxima (regime de compensação de horas), o desconto ou contribuição assistencial, as contribuições de empresas aos seus sindicatos, e o período de vigência do instrumento. Numa posição intermediária, 
encontravam-se três tópicos temáticos enfocados em pelo menos seis e não mais do que nove acordos coletivos da amostra. Estes referiam-se a cláusulas sobre jornada extraordinária (regime de compensação de horas para mulheres e menores) e sanções aplicáveis às empresas que não transferissem as taxas e contribuições sindicais no prazo ajustado. Finalmente, um montante de 22 tópicos temáticos consistia de assuntos abordados em não mais do que quatro acordos coletivos, dentre os quais 14 tópicos apareciam em apenas um acordo coletivo da amostra. Dentre estes tópicos temáticos de baixa freqüência encontram-se, por exemplo, o adicional por tempo de serviço, as normas sobre resolução de disputas através da Justiça do Trabalho, a contribuição financeira de empresas individuais a sindicatos de trabalhadores, a data-base de revisão do dissídio coletivo, os salários mínimos, e a identificação das partes (exclusive o preâmbulo).

Quadro 2: Tópicos temáticos cobertos por pelo menos um acordo coletivo, em acordos coletivos selecionados da indústria de transformação do Rio Grande do Sul, 1978

\begin{tabular}{|c|c|}
\hline Cláusulas substantivas & Cláusulas de procedimento \\
\hline $\begin{array}{l}\text { Remuneração } \\
\text { - Reajuste dos salários nominais baseado no } \\
\text { - Reajunto do custo de vida } \\
\text { aumento da salários nominais baseado no } \\
\text { ("aumento real") } \\
\text { - Reajuste dos salários nominais de } \\
\text { empregado admitido após a última data- } \\
\text { base de revisão de dissídio (empregado } \\
\text { novo) } \\
\text { - Política salarial } \\
\text { - Normas complementares sobre reajuste dos } \\
\text { salários nominais } \\
\text { - Salários minimos } \\
\text { - Adicional por tempo de serviço } \\
\text { - Adicional de insalubridade } \\
\text { Jornada de trabalho } \\
\text { - Distribuição da jornada semanal normal } \\
\text { máxima: Regime de compensação de horas } \\
\text { - Jornada extraordinária: Regime de } \\
\text { compensação de horas (mulheres) } \\
\text { - Jornada extraordinária: Regime de } \\
\text { compensação de horas (menores) } \\
\text { Férias e licenças remuneradas } \\
\text { - Licença remunerada: Estudante } \\
\text { Segurança no emprego e rescisão do contrato } \\
\text { de trabalho } \\
\text { - Gravidez } \\
\text { Condiçóes de trabalho } \\
\text { - Uniforme }\end{array}$ & $\begin{array}{l}\text { Relações sindicais } \\
\text { - Acesso do sindicato ao local de trabalho } \\
\text { - Desconto/contribuição assistencial } \\
\text { - Dedução de contribuição sindical } \\
\text { de empribuição de empregadores a sindicato } \\
\text { Procedimentos de negociação e de resolução } \\
\text { de conflitos } \\
\text { - Extensão do período de vigência do acordo } \\
\text { coletivo } \\
\text { - Registro do acordo coletivo na Delegacia } \\
\text { Regional do Trabalho } \\
\text { - Cumprimento do acordo coletivo } \\
\text { - Justiça do Trabalho } \\
\text { Normas complementares sobre o acordo } \\
\text { coletivo } \\
\text { - Partes (não no preâmbulo) } \\
\text { - Data-base } \\
\text { - Período de vigência } \\
\text { tebertura do acordo: categorias e base } \\
\text { Sançôes } \\
\text { - Atraso na transferência de taxas e } \\
\text { contribuições sindicais } \\
\text { - Descumprimento de cláusula (geral) } \\
\text { Sindicatos de empregadores } \\
\text { - Finanças de sindicatos de empregadores }\end{array}$ \\
\hline
\end{tabular}


Os seis tópicos temáticos de maior freqüência correspondiam a $56,1 \%$ de todas as cláusulas ajustadas em 1978. Em conjunto com os três tópicos de freqüência intermediária, totalizavam $77,0 \%$ do número de cláusulas. Isto significa que mais de três quartos das cláusulas negociadas em 1978 restringia-se a apenas nove tópicos temáticos. Além disso, estes tópicos respondiam por pelo menos $60,0 \%$ das cláusulas em cada acordo individual da amostra, à exceção do acordo dos metalúrgicos de São Leopoldo. Esta concentração de cláusulas em um conjunto extremamente limitado de assuntos é uma evidência clara da estreiteza dos acordos coletivos ao final dos anos 1970. Os tópicos de frequências alta e intermediária compreendem o que pode ser considerado o acordo coletivo típico de 1978. Este acordo típico consistia das seguintes cláusulas:

- Reajuste dos salários nominais com base no aumento do custo de vida para empregados contratados até a data-base imediatamente anterior. Uma característica saliente do sistema brasileiro de relações de trabalho tem sido a revisão anual dos acordos coletivos, em nível de setor ou categoria, no que se denomina a data-base de revisão do dissídio coletivo. Cada unidade de negociação possui sua própria data-base. No período 1978-95, as cláusulas de reajuste salarial habitualmente estipulavam um percentual de aumento dos salários nominais com base em algum indicador de variação no custo de vida no período de 12 meses antes da data-base. Em 1978, um dos acordos apresentou, todavia, uma cláusula de reajuste dos salários nominais baseado em outro indicador ("aumento real") sem ter convencionado sobre o reajuste com base no custo de vida. Esta pode ser considerada, de fato, uma diferença menos relevante sobre como expressar as regras de reajuste de salários monetários em regimes de alta inflação. Em 1978, ademais, normas estatais de política salarial estabeleciam um piso de reajuste a ser aplicado aos salários na data-base, independentemente dos acordos coletivos que as partes viessem a celebrar. Ou seja, em termos do comportamento do poder aquisitivo dos salários, pouco importa se o aumento nos salários monetários fosse denominado reajuste salarial ou aumento real, ou mesmo recebesse um outro título qualquer. Ao final dos anos 1970, assim como durante todo o período de análise, o ponto central das negociações sobre salários consistiu do percentual de aumento salarial a ser adicionado ao percentual estabelecido por lei ou piso de reajuste. Em 1978, todos os acordos coletivos da amostra incluíram cláusulas sobre reajuste salarial. 
- Reajuste dos salários nominais com base no aumento do custo de vida para empregados contratados após a data-base imediatamente anterior. Em 1978, as normas estatais sobre indexação salarial fixavam taxas de reajuste a serem aplicadas a empregados que estivessem contratados na data-base imediatamente anterior, deixando uma lacuna sobre as taxas aplicáveis a empregados contratados posteriormente, as quais poderiam ser coletivamente negociadas a fim de se tornarem imperativas. Em geral, os acordos da amostra estabeleceram estas taxas proporcionalmente à taxa legal: quanto mais distante da data-base corrente tivesse sido contratado o empregado, maior seria seu percentual de reajuste salarial.

- Distribuição da jornada semanal normal máxima de trabalho. A jornada legal normal máxima de trabalho era de 48 horas por semana e oito horas por dia em 1978. Se um empregado trabalhasse mais do que oito horas por dia, este empregado teria direito a uma remuneração extraordinária. Cláusulas sobre a distribuição da jornada semanal normal de trabalho consistiam, via-de-regra, em uma autorização aos empregadores individuais para requerer os serviços diários do trabalho de seus empregados por mais do que oito horas sem ter que remunerá-los por jornada extraordinária, desde que a jornada semanal não excedesse a 48 horas. Configuravam, pois, normas que ofereciam algum grau de flexibilidade à distribuição da jornada em contraste com o padrão legal. Em alguns acordos da amostra, incluíram-se outras cláusulas diretamente associadas a esta cláusula básica. Os casos típicos referiam-se à necessidade de os empregadores obterem permissão especial do Ministério do Trabalho ou do sindicato de empregados a fim de aplicar o regime de compensação de horas a mulheres e menores;

- Desconto ou contribuição assistencial. Em geral, as cláusulas sobre este tópico estabeleciam uma fração dos salários de cada empregado a ser deduzida pelas empresas, independentemente de o empregado ser associado ao sindicato, e automaticamente transferida ao sindicato. Uma cláusula bastante próxima a esta era a que fixava uma penalidade às empresas que não procedessem ao desconto dos salários e à transferência dos recursos ao sindicato no prazo convencionado no acordo;

- Finanças dos sindicatos de empregadores. Os sindicatos de empregadores também tiravam vantagem da celebração de acordos coletivos para garantir recursos financeiros às suas atividades. 
Em nove acordos coletivos da amostra, registraram-se cláusulas que obrigavam as empresas individuais a contribuir financeiramente com o sindicato dos empregadores, independentemente de serem associadas. De modo similar ao tópico anterior, uma cláusula associada era a que definia uma penalidade às empresas que falhassem no recolhimento de suas contribuições; e

- Vigência. Cláusulas que fixavam o período de vigência dos acordos coletivos em um ano foram registradas em praticamente todos os acordos.

O acordo coletivo típico de 1978 consistia, pois, de normas sobre seis assuntos. As regras sobre temas substantivos compreendiam os tópicos sobre reajuste salarial e distribuição da jornada de trabalho, enquanto as normas de procedimento referiam-se ao período de vigência dos acordos e ao provimento de fundos de financiamento para os sindicatos de empregados e de empregadores. Este conjunto restrito de tópicos formou a base a partir da qual o escopo temático dos acordos passou a se expandir em fins dos anos 1970.

\subsection{A expansão do escopo temático}

Entre 1978 e 1995, o escopo temático dos acordos coletivos da amostra expandiu-se em paralelo ao rápido crescimento no número de cláusulas que os compunham. Esta expansão do escopo temático pode ser evidenciada com base nos seguintes fatos:

a) Um número crescente de tópicos temáticos foi registrado em todos os acordos coletivos da amostra, indicando uma maior variedade de assuntos que mereceram a atenção dos agentes de negociação nas unidades selecionadas; e

b) Um número crescente de acordos coletivos da amostra incorporou novos tópicos temáticos, mostrando que a maior variedade de assuntos observada no conjunto da amostra não ficou confinada a um ou outro acordo coletivo individual.

A tabela 5 apresenta a evidência sobre o aumento no número de tópicos temáticos enfocados em pelo menos um acordo coletivo da amostra e no número de tópicos temáticos cobertos por uma proporção crescente de acordos entre 1978 e 1995. Os dados foram agrupados para os anos de 1978 e 1995, bem como para os períodos identificados na subseção precedente. 
Tabela 5: Número e percentagem de tópicos temáticos segundo sua cobertura por acordos coletivos selecionados da indústria de transformação do Rio Grande do Sul, 1978-95

\begin{tabular}{|c|c|c|c|c|c|c|c|c|c|c|c|c|}
\hline \multirow{3}{*}{$\begin{array}{l}\text { Cobertura lem } \\
\% \text { dos acordos) }\end{array}$} & \multicolumn{12}{|c|}{ Número e percentagem de tópicos temáticos' } \\
\hline & \multicolumn{2}{|c|}{1978} & \multicolumn{2}{|c|}{1978.81} & \multicolumn{2}{|c|}{$1982-84$} & \multicolumn{2}{|c|}{$1985-88$} & \multicolumn{2}{|c|}{$1989-95$} & \multicolumn{2}{|c|}{1995} \\
\hline & $N$ & (\%) & $N^{2}$ & $(\%)$ & $\mathrm{N}^{2}$ & (\%) & $N^{2}$ & $|\%|$ & $\mathrm{N}^{2}$ & (\%) & $N$ & (1\%) \\
\hline Zero & 134 & 82,2 & 118,0 & 72,4 & 80,7 & 49,5 & 57,3 & 35,1 & 22,1 & 13,6 & 15 & 9,2 \\
\hline Não. & 29 & 17,8 & 45,0 & 27,6 & 82,3 & 50,5 & 105,7 & 64,9 & 140,9 & 86,4 & 148 & 90,8 \\
\hline$[0,25)$ & 154 & 94,5 & 142,3 & 87,3 & 130,4 & 80,0 & 117,8 & 72,2 & 90,8 & 55,8 & 87 & 53,4 \\
\hline$[25,5$ & 3 & 1,8 & 11,0 & 6,7 & 15,7 & 9,6 & 19,3 & 11,8 & 31,0 & 19,0 & 28 & 17,2 \\
\hline$[50$, & 1 & 0,6 & 4,8 & 2,9 & 9,7 & 5,9 & 12,3 & 7,5 & 16,4 & 10,1 & 24 & 14,7 \\
\hline 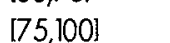 & 5 & 3,1 & 5,0 & 31 & 73 & 4,5 & 13,8 & 8,4 & 24,7 & 15,2 & 24 & 147 \\
\hline [100] & 0 & 0,0 & 2.0 & 1,2 & 1,7 & 1,0 & 40 & 2,5 & 6,4 & 3,9 & 5 & 3,1 \\
\hline
\end{tabular}

${ }^{1}$ O nümero total de tópicos temáticos no esquema de classificação é 163.

${ }^{2}$ Média anual do período.

O alargamento do escopo temático dos acordos coletivos pode também ser evidenciado através de estatísticas sobre o grau de concentração e o coeficiente de Gini para a distribuição de cláusulas por tópicos temáticos e grupos temáticos. O grau de concentração $\left(C_{i}\right)$ apresenta a percentagem acumulada de elementos classificados em um montante fixo i de classes de uma distribuição, sob condição de que estes elementos sejam os de maior freqüência individual. Consideremos a distribuição das cláusulas por tópicos temáticos: quanto menor for $\mathrm{C}_{\mathrm{i}}$, menor será a percentagem de cláusulas limitadas a um montante fixo i de tópicos temáticos. Assim, menores valores de $\mathrm{C}_{\mathrm{i}}$ ao longo do tempo são um sinal de ampliação do escopo temático das negociaçōes coletivas. A tabela 6 apresenta as estatísticas do grau de concentração da distribuição de cláusulas por tópicos temáticos e grupos temáticos, considerando os seguintes valores para o montante i:

(1) $\mathrm{C}_{10}=\mathrm{P}_{10} / \mathrm{N}$, para a distribuiçãa de cláusulas por tópicos temáticos;

onde

$\mathrm{C}_{10}=$ grau de concentração da distribuição de cláusulas por tópicos temáticos;

$\mathrm{P}_{10}=$ montante acumulado de cláusulas classificadas nos dez tópicos temáticos de maior freqüência de cláusulas;

$\mathrm{N}=$ número total de cláusulas $\mathrm{e}$

(2) $\mathrm{C}_{4}=\mathrm{P}_{4} / \mathrm{N}$, para a distribuição de cláusulas por grupos temáticos; 
onde

$\mathrm{C}_{4}=$ grau de concentração da distribuição de cláusulas por grupos temáticos;

$\mathrm{P}_{4}=$ montante acumulado de cláusulas classificadas nos quatro grupos temáticos de maior freqüência de cláusulas;

$\mathrm{N}=$ número total de cláusulas.

Tabela 6: Grau de concentração e coeficiente de Gini para as distribuiçōes de cláusulas por tópicos e grupos temáticos, em acordos coletivos selecionados da indústria de transformação do Rio Grande do Sul, 1978-95

\begin{tabular}{l|r|r|r|r|r|r}
\hline & 1978 & $1978-81$ & $1982-84$ & $1985-88$ & $1989-95$ & 1995 \\
\hline Tópicos temáticos $^{1}$ & & & & & & \\
\hline Gini & 0,921 & 0,861 & 0,754 & 0,681 & 0,566 & 0,524 \\
$C_{10}(\%)$ & 79,1 & 60,5 & 35,9 & 29,9 & 23,9 & 22,4 \\
\hline Grupos temáticos $^{2}$ & & & & & & \\
\hline Gini & 0,77 & 0,647 & 0,473 & 0,454 & 0,439 & 0,430 \\
& 8 & & & & & \\
$C_{L}(\%)$ & 66,2 & 51,4 & 33,9 & 33,0 & 33,9 & 33,1 \\
\hline
\end{tabular}

1 O numero total de tópicos temáticos no esquema de classificação é 163.

${ }^{2} \mathrm{O}$ número total de grupos temáticos no esquema de classificação é 32.

A tabela 6 mostra também o coeficiente de Gini (G) para a distribuição de cláusulas por tópicos e grupos temáticos. $O$ coeficiente $G$ pode variar entre 0 e 1: quanto mais próximo $G$ estiver da unidade, mais desigual é a distribuição, e vice-versa. Consideremos novamente a distribuição de cláusulas por tópicos temáticos: um valor de $G$ próximo à unidade indicaria uma concentração de cláusulas em uns poucos tópicos temáticos, ao passo que um valor próximo a zero indicaria uma distribuição menos desigual entre os tópicos.

Os dados da tabela 6 reforçam a conclusão sobre o alargamento do escopo temático dos acordos coletivos da amostra. Em primeiro lugar, o grau de concentração das cláusulas por tópicos temáticos $\left(C_{10}\right)$ diminuiu de $79,1 \%$ em 1978 para $22,4 \%$ em 1995 . Uma tendência similar à desconcentração é evidenciada nos resultados do grau de concentração das cláusulas por grupos temáticos $\left(\mathrm{C}_{4}\right)$. Em segundo lugar, o coeficiente de Gini para a distribuição das cláusulas por tópicos temáticos mostrou constante redução de 0,921 em 1978 para 0,524 em 1995. Esta redução significou que um maior número de cláusulas veio a enfocar um maior número de tópicos temáticos. 
A evidência analisada até este ponto demonstra o alargamento do escopo temático sem abordar os assuntos que vieram a ser tratados nos acordos coletivos da amostra. Na tabela 7, o número médio e a percentagem de cláusulas por temas são apresentados, permitindo, assim, a identificação das classes de assuntos que foram majoritariamente negociadas nas unidades selecionadas. Os dados da tabela mostram que o número de cláusulas substantivas e de procedimento multiplicou-se após o final dos anos 1970, ainda que por diferentes taxas de crescimento. Este ritmo de crescimento desigual ocasionou uma mudança expressiva na participação de cada categoria no total de cláusulas. Assim, enquanto uma e outra categoria, tomadas individualmente, representavam cerca de metade do total de cláusulas em 1978, a percentagem das cláusulas substantivas chegou a $83,5 \%$ em 1995 .

Tabela 7: Número médio e percentagem de cláusulas por temas, em acordos coletivos selecionados da indústria de transformação do Rio Grande do Sul, 1978-95

\begin{tabular}{|c|c|c|c|c|c|c|c|c|c|c|c|c|}
\hline \multirow[t]{2}{*}{ Temas } & \multicolumn{2}{|c|}{1978} & \multicolumn{2}{|c|}{$1978-81$} & \multicolumn{2}{|c|}{$1982-84$} & \multicolumn{2}{|c|}{ 1984-88 } & \multicolumn{2}{|c|}{$1989-95$} & \multicolumn{2}{|c|}{1995} \\
\hline & $\mathrm{N}$ & $(\%)$ & $N$ & $(\%)$ & $\mathrm{N}$ & (\%) & $N$ & $(\%)$ & $N$ & (8) & $\mathrm{N}$ & (\%) \\
\hline Normas substantivas & 4,1 & 50,4 & 9,8 & 69,8 & 19,3 & 77,5 & 29,7 & 79,7 & 47,4 & 81,7 & 53,5 & $\overline{83,5}$ \\
\hline Remuneração & $2 ; 4$ & 29,5 & 4,8 & 34,9 & 7,8 & 31,5 & 11,9 & 32,0 & 20,1 & 34,6 & 22,3 & 34,8 \\
\hline Jornada de trabalho & 1,5 & 18,7 & 2,3 & 17,1 & 3,3 & 13,3 & 4,0 & 10,8 & 5,0 & 8,6 & 6,3 & 9,8 \\
\hline Férias e licenças & 0,1 & 0,7 & 0,3 & 2,1 & 0,9 & 3,5 & 1,9 & 4,8 & 4,6 & 7,8 & 5,8 & 9,1 \\
\hline $\begin{array}{l}\text { Recrutamento e contrato de } \\
\text { trabolho }\end{array}$ & & & 0,3 & 1,4 & 1,2 & 5,0 & 2,4 & 6,4 & 4,2 & 7,2 & 4,5 & 7,1 \\
\hline Segurança no emprego & 0,1 & 0,7 & 1,4 & 7,4 & 3,9 & 15,6 & 6,1 & 16,4 & 8,0 & 13,9 & 7,8 & 12,2 \\
\hline Trabalho temporário & - & & - & & & & - & & 0,0 & 0,0 & 0,1 & 0,1 \\
\hline Treinamento & . & & - & & 0,1 & 0,2 & 0,1 & 0,3 & 0,2 & 0,3 & 0,3 & 0,5 \\
\hline Condiçōes de trabalho & 0,1 & 0,7 & 0,7 & 3,4 & 2,1 & 8,3 & 3,2 & 8,6 & 5,3 & 9,2 & 7,0 & 10,9 \\
\hline Normas de procedimento & 4,1 & 49,6 & 4,2 & 30,2 & 5,6 & 22,5 & 7,6 & 20,3 & 10,5 & 18,3 & 10,6 & 16,5 \\
\hline Relações sindicais & 1,2 & 15,1 & 1,3 & 9,1 & 1,8 & 7,1 & 2,6 & 6,9 & 4,2 & 7,3 & 4,5 & 7,0 \\
\hline Procedimentos de negociação & 0,5 & 5,8 & 0,3 & 2,4 & 0,4 & 1,4 & 0,7 & 1,7 & 1,6 & 2,7 & 1,4 & 2,2 \\
\hline Normas complementares & 1,3 & 15,8 & 1,2 & 8,9 & 1,1 & 4,4 & 1,1 & 3,0 & 1,5 & 2,7 & 1,6 & 2,5 \\
\hline Sançōes & 0,4 & 5,0 & 0,6 & 4,0 & 1,4 & 5,6 & 1,9 & 5,1 & 1,6 & 2,8 & 1,5 & 2,3 \\
\hline Sindicatos de empregadores & 0,6 & 7,9 & 0,8 & 5,8 & 1,0 & 4,0 & 1,3 & 3,5 & 1,6 & 2,8 & 1,7 & 2,6 \\
\hline Total & 8,2 & 100,0 & 13,9 & 100,0 & 24,9 & 100,0 & 37,2 & 100,0 & 57,9 & 100,0 & 64,1 & 100,0 \\
\hline
\end{tabular}

O tema mais importante na classe das cláusulas de procedimento foi o das relaçōes sindicais, que reúne majoritariamente direitos institucionais de sindicatos de trabalhadores. Este tema representou $7,3 \%$ do total de cláusulas (ou 36,2\% das cláusulas de procedimento) entre 1978 e 1995, enfocando assuntos tais como o acesso de representantes do sindicato aos locais de trabalho, a liberação de dirigen- 
te sindical de suas obrigações de trabalho para a realização de atividades do sindicato, o fornecimento de informações ao sindicato, fontes de financiamento do sindicato, e delegados sindicais. Outros temas individuais na classe das cláusulas de procedimento mostraram menor participação relativa.

$\mathrm{Na}$ classe das cláusulas substantivas, as negociações nas unidades da amostra concentraram-se em seis temas: remuneração, jornada de trabalho, férias e licenças remuneradas, recrutamento e contrato de trabalho, segurança no emprego e rescisão do contrato de trabalho, e condiçóes de trabalho. Em conjunto, estes seis temas representaram $79,5 \%$ do total de cláusulas convencionadas entre 1978 e 1995. O tema da remuneração foi, dentre todos, o de maior participação, contribuindo com aproximadamente um terço do total de cláusulas. Outros temas registraram menores proporções de cláusulas. Em ordem decrescente de importância, temos: segurança no emprego e rescisão do contrato de trabalho (14,3\%), jornada de trabalho $(10,3 \%)$, condições de trabalho $(8,6 \%)$, recrutamento e contrato de trabalho $(6,4 \%)$, e férias e licenças remuneradas $(6,3 \%)$.

As variaçōes na percentagem de cláusulas classificadas em cada tema indicam mudanças de foco temático dos agentes de negociação ao longo do período. As cláusulas substantivas podem ser divididas em quatro grupos conforme estas variações. O primeiro grupo consiste de cláusulas sobre férias e licenças remuneradas, recrutamento e contrato de trabalho, e condições de trabalho, cuja participação cresceu de modo constante entre 1978 e 1995. Em conjunto, estes três temas representavam $7,1 \%$ do total de cláusulas no período $1978-81$, tendo alcançado $25,3 \%$ no período $1989-95$. O segundo grupo compreende as cláusulas sobre jornada de trabalho, cuja percentagem mostrou uma propensão a diminuir entre o final dos anos $1970(17,1 \%)$ e a primeira metade dos anos $1990(8,6 \%)$, não obstante uma tênue recuperação observada em 1994-95. O terceiro grupo é formado por cláusulas sobre segurança no emprego e rescisão do contrato de trabalho. As variações em sua proporção assemelharam-se a um $U$ invertido. Ou seja, após crescer de 7,4\% no período $1978-81$ para $16,4 \%$ no período $1985-88$, com pico de $17,3 \%$ em 1986, a percentagem de cláusulas classificadas neste tema recuou para $13,9 \%$ em 1989-95. Por fim, o quarto grupo reúne as cláusulas sobre remuneração, cuja proporção mostrou uma variação bastante próxima à média de 33,7\% registrada entre 1978 e 1995. 
Apesar do alargamento do escopo temático dos acordos coletivos a partir de fins dos anos 1970, o grau de concentração das cláusulas em assuntos específicos permanecia um tanto elevado nas unidades de negociação em meados dos anos 1990. Em 1995, dez tópicos temáticos representaram $22,4 \%$ das cláusulas contratadas, e quatro grupos temáticos reuniram $33,1 \%$ das cláusulas. Além disso, apenas 48 tópicos temáticos tinham sua cobertura relativamente dispersa entre os acordos coletivos da amostra, com metade ou mais destes acordos incluindo pelo menos uma cláusula sobre cada um destes tópicos. Isto sugere a existência de limites para uma maior ampliação do escopo temático dos acordos da amostra, cuja investigação escapou aos objetivos deste trabalho. Na próxima subseção, detalho o escopo temático dos acordos em 1995.

\subsection{0 escopo temático dos acordos coletivos em 1995}

Ao final dos anos 1970, os acordos coletivos da amostra compunham-se de um pequeno número de cláusulas que enfocavam um limitado conjunto de assuntos das relações de trabalho. Cerca de $80,0 \%$ do total das cláusulas correspondia a dez tópicos temáticos $\left(\mathrm{C}_{10}=79,1 \%\right)$. Este conjunto foi referido como o acordo coletivo típico de 1978. O expressivo crescimento no número de cláusulas, acompanhado por uma ampliação do escopo temático das negociações, determinou um quadro bastante diferente, nas unidades de negociação selecionadas, em 1995. Nesta subseção, apresento o que pode ser denominado o acordo coletivo típico de $1995 \mathrm{com}$ base nos tópicos temáticos enfocados por um número expressivo de cláusulas e com cobertura em um número considerável de acordos coletivos da amostra.

Os assuntos correspondentes a um número expressivo de cláusulas foram determinados segundo os coeficientes de concentração de cláusulas por tópicos temáticos e grupo temáticos. Em 1995, um pouco mais do que uma dentre cinco cláusulas foi classificada em dez tópicos temáticos de maior freqüência $\left(C_{10}=22,4 \%\right)$, enquanto quatro grupos temáticos responderam por um terço do total de cláusulas $\left(\mathrm{C}_{4}=33,1 \%\right)$. Quanto à cobertura de tópicos temáticos individuais por um número considerável de acordos coletivos, considerei os 48 tópicos que foram enfocados em pelo menos a metade dos acordos como representativos de um acordo coletivo típico da amos- 
tra em 1995. A tabela 8 apresenta a lista de tópicos temáticos e grupos temáticos com maiores percentagens de cláusulas, ao passo que a tabela 9 mostra a lista de tópicos temáticos cobertos em metade ou mais dos acordos coletivos da amostra. Estes 48 tópicos temáticos, que se compõem de 41 tópicos substantivos e sete tópicos de procedimento, representaram $66,6 \%$ do total de cláusulas em 1995. O tema da remuneração totalizou 21 tópicos.

Tabela 8: Tópicos temáticos e grupos temáticos com as maiores percentagens de cláusulas, em acordos coletivos selecionados da indústria de transformação do Rio Grande do Sul, 1995

\begin{tabular}{|c|c|}
\hline Tópicos temáticos $(\mathrm{ClO}=22,4 \%)$ & Grupos temáticos $(\mathrm{C} 4=33,1 \% \mid$ \\
\hline Condições de trabalho: uniforme $(2,7 \%)$ & Reajuste dos salários nominais $(00,9 \%)$ \\
\hline Obrigação de registrar na carteira de trabalho $(2,6 \%)$ & $\begin{array}{l}\text { Procedimentos administrativos sobre remuneração } \\
(9,7 \%)\end{array}$ \\
\hline Finanças de sindicatos de empregadores $(2,6 \%)$ & $\begin{array}{l}\text { Salários indiretos e auxilios }(6,7 \%) \text { Jornada normal } \\
\text { de trabalho }(5,8 \%)\end{array}$ \\
\hline $\begin{array}{l}\text { Normas complementares sobre reajuste dos salários } \\
\text { nominais }(2,5 \%)\end{array}$ & \\
\hline Relações sindicais: Informação e comunicação $(2,4 \%)$ & \\
\hline $\begin{array}{l}\text { Procedimentos administrativos para rescisão do } \\
\text { contrato: Documentos e comunicação }(2,3 \%)\end{array}$ & \\
\hline $\begin{array}{l}\text { Aviso-prévio: Rescisão antes de se completar o } \\
\text { período de aviso-prévio }(1,9 \%)\end{array}$ & \\
\hline $\begin{array}{l}\text { Segurança do trabalho: Equipamento de proteção } \\
(1,9 \%)\end{array}$ & \\
\hline $\begin{array}{l}\text { Distribuição da jornada semanal normal máxima: } \\
\text { Regime de compensação de horas }(\Pi, 8 \%)\end{array}$ & \\
\hline Registro de ingresso e saida $(1,8 \%)$ & \\
\hline
\end{tabular}

Tabela 9: Tópicos temáticos enfocados em metade ou mais de acordos coletivos selecionados da indústria de transformação do Rio Grande do Sul, por grupos temáticos, 1995

\begin{tabular}{l|c|c}
\hline \multicolumn{1}{c|}{ Tópicos temáticos } & Acordos(\%)1 & Cáusulas(\%)2 \\
\hline Reajuste dos salários nominais & 100 & 1,56 \\
Reajuste dos salários nominais baseado no aumento do custo de vida & 67 & 1,04 \\
Reajuste dos salários nominais baseado no aumento da produtividade & & \\
ou outro ("aumento real") & 100 & 1,56 \\
Reajuste dos salários nominais de empregado admitido após a última & 60 & 0,94 \\
data-base de revisão de dissídio (empregado novol & 87 & 2,50 \\
Política de reajuste salarial & 93 & 1,46 \\
Normas complementares sobre reajuste dos salários nominais & 67 & 1,04 \\
Salários mínimos &
\end{tabular}




\begin{tabular}{|c|c|c|}
\hline Tópicos temáticos & Acordos $(\%)$ & Cláusulas $(\%) 2$ \\
\hline Procedimentos administrativos sobre remuneração & & 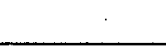 \\
\hline $\begin{array}{c}\text { Data de pagamento da diferença de salário decorrente do acordo } \\
\text { coletivo }\end{array}$ & 53 & 1,14 \\
\hline Forma de pagamento & 67 & 1,04 \\
\hline Adiantamento de salário & 73 & 1,35 \\
\hline Recibos e demonstrativos de pagamento & 80 & 1,25 \\
\hline Deduções & 87 & 1,35 \\
\hline Atestado médico para garantia de remuneração & 53 & 0,83 \\
\hline Atrasos & 60 & 0,94 \\
\hline Horas extras & & \\
\hline Taxa geral & 80 & 1,25 \\
\hline Domingos, feriados, descanso semanal & 60 & 0,94 \\
\hline Adicionais e gratificasões de salário (exclusive horas extras) & & \\
\hline Adicional por tempo de serviço & 73 & 1,14 \\
\hline Antecipação de $13^{\circ}$ salário & 53 & 0,83 \\
\hline Pagamento de $13^{*}$ salário em casos especiais & 60 & 0,94 \\
\hline Salários indir etos e auxillios & & \\
\hline Educação & 80 & 1,35 \\
\hline Auxilio-funeral & 87 & 1,35 \\
\hline Jornada normal de trabalho & & \\
\hline $\begin{array}{c}\text { Distribuição da jornada semanal normal máxima: Regime de } \\
\text { compensação de horas }\end{array}$ & 100 & 1,77 \\
\hline Registro de ingresso e saída & 67 & 1,77 \\
\hline Insalubridade: Regime de compensação de horas & 80 & 1,25 \\
\hline bornada de mulheres & & \\
\hline Amamentação & 53 & 0,83 \\
\hline Jornada de menores & & \\
\hline Jor nada extraordinária: Regime de compensação de horas & 53 & 0,83 \\
\hline Normas especiais sobre jornada de trabalho & & \\
\hline Extensão de feriados: Regime de compensação de hor as & 93 & 1,46 \\
\hline Férias & & \\
\hline Data de ińcio do período de gozo & 60 & 0,94 \\
\hline $\begin{array}{l}\text { Empregado com período aquisitivo incompleto: Antecipação do } \\
\text { período de gozo }\end{array}$ & 53 & 0,94 \\
\hline Empregado com período aquisitivo incompleto: Pagamento & 67 & 1,04 \\
\hline Licença remunerada & & \\
\hline Falecimento de parentes & 60 & 0,94 \\
\hline Estudante & 80 & 1,25 \\
\hline $\begin{array}{c}\text { Registros e comunicacões } \\
\text { Obrigação de registrar na carteira de trabatho }\end{array}$ & 93 & 2,60 \\
\hline
\end{tabular}




\begin{tabular}{|c|c|c|}
\hline Tópicos temáticos & Acordos $(\%)$ & Cláusulas(\%)2 \\
\hline $\begin{array}{l}\frac{\text { Seguranca no emprego }}{\text { Gravidez }} \\
\text { Empregado próximo da aposentadoria }\end{array}$ & $\begin{array}{l}93 \\
87 \\
\end{array}$ & $\begin{array}{l}1,46 \\
1,35 \\
\end{array}$ \\
\hline $\begin{array}{c}\text { Procedimentos administrativos para rescisão do contrato } \\
\text { Data-limite para pagamentos após rescisão do contrato de trabalho } \\
\text { Documentos e comunicação }\end{array}$ & $\begin{array}{l}60 \\
80 \\
\end{array}$ & $\begin{array}{l}0,94 \\
2,29 \\
\end{array}$ \\
\hline $\begin{array}{l}\text { Aviso-prévio } \\
\text { Rescisão antes de se completar o período de aviso-prévio } \\
\text { Tempo parc procura de novo emprego }\end{array}$ & $\begin{array}{l}93 \\
53 \\
\end{array}$ & $\begin{array}{l}1,87 \\
0,83\end{array}$ \\
\hline $\begin{array}{l}\text { Ambiente de trabalho e bem-estar } \\
\text { Uniforme }\end{array}$ & 100 & 2,71 \\
\hline $\begin{array}{c}\text { Sequrança } \\
\text { Equipamento de proteção }\end{array}$ & 67 & 1,87 \\
\hline $\begin{array}{c}\text { Facilidades co sindicato de empregados } \\
\text { Acesso ao local de trabalho }\end{array}$ & 67 & 1,04 \\
\hline $\begin{array}{l}\text { Informaşão e comunicação } \\
\text { Informação e comunicação }\end{array}$ & 87 & 2,39 \\
\hline $\begin{array}{l}\text { Financas do sindicato de empregados } \\
\text { Desconto/contribuição assistencial } \\
\text { Dedução de contribuição sindical }\end{array}$ & $\begin{array}{l}93 \\
80 \\
\end{array}$ & $\begin{array}{l}1,46 \\
1,25\end{array}$ \\
\hline $\begin{array}{c}\text { Normas complementares sobre o acordo coletivo } \\
\text { Período de vigência }\end{array}$ & 100 & 1,56 \\
\hline $\begin{array}{c}\text { Sanções } \\
\text { Atraso na transferência de faxas e contribuiçōes sindicais }\end{array}$ & 73 & 1,56 \\
\hline $\begin{array}{l}\text { Finanças de sindicatos de empregadores } \\
\text { Finanças de sindicatos de empregadores }\end{array}$ & 87 & 2,60 \\
\hline
\end{tabular}

${ }^{1}$ Percentagem dos acordos coletivos da amostra que apresentam cláusula sobre o tópico temático. ${ }^{2}$ Percentagem das cláusulas classificadas no tópico temático.

Nesta seção, analisei a ampliação do escopo temático dos acordos coletivos selecionados da indústria de transformação do Rio Grande do Sul entre 1978 e 1995. Em 1978, os acordos da amostra cobriam um estreito leque de assuntos. Um acordo coletivo típico daquele ano compreendia normas sobre o reajuste dos salários nominais com base no custo de vida, a distribuição da jornada semanal normal de trabalho, fontes de financiamento para sindicatos de empregados e de empregadores, e o período de vigência dos acordos. Durante os anos 1980 e a primeira metade dos anos 1990, o número de cláusulas aumentou de modo expressivo. Uma varieda- 
de de novos assuntos tornou-se objeto de negociação, a maioria deles sobre a relação de emprego. Em conseqüência, as cláusulas substantivas representaram $79,8 \%$ e as cláusulas de procedimento apenas $20,2 \%$ do total de cláusulas dos acordos da amostra entre 1978 e 1995. O alargamento do escopo temático não se restringiu a umas poucas unidades de negociação; ao contrário, todos os acordos coletivos da amostra mostravam um escopo consideravelmente maior em 1995 quando comparado ao ano de 1978.

\section{Conclusão}

Neste artigo, analisei o crescimento no número de cláusulas e o conseqüente alargamento do escopo temático nas unidades de negociação selecionadas da indústria de transformação do Rio Grande do Sul entre 1978 e 1995. Em 1978, os acordos coletivos da amostra consistiam de normas sobre reajustamento salarial sob um contexto de alta e persistente inflação, flexibilização do cumprimento da jornada normal de trabalho vis-à-vis a legislação estatal, fontes de financiamento para sindicatos de empregados e de empregadores, e o período de vigência dos acordos. Este conjunto de tópicos era abordado em pelo menos a metade dos acordos, o que permitiu denominá-lo de acordo coletivo típico de 1978.

A iniciativa dos sindicatos de trabalhadores em pressionar os empregadores a negociar coletivamente normas sobre a relação de emprego e outras deflagrou um rápido crescimento no número de cláusulas convencionadas a partir de fins dos anos 1970. De uma média de 8,2 cláusulas por acordo em 1978, este processo resultou em uma média de 64,1 cláusulas por acordo em 1995. Este resultado deve ser entendido como um sinal de fortalecimento das negociações coletivas como método de regulação das relações de trabalho nas unidades selecionadas.

O alargamento do escopo temático manifestou-se num crescente número de assuntos abordados, que não se restringiram a umas poucas unidades de negociação. Em 1978, o conjunto dos dez mais freqüentes tópicos temáticos representou $79,1 \%$ do total de cláusulas, enquanto em 1995 esta percentagem havia declinado para 22,4\%, indicando a presença de uma maior variedade de assuntos nos acordos coletivos. Neste mesmo período, o coeficiente de Gini decresceu de 0,921 para 0,524. Em 1995, um conjunto de 48 tópicos temáticos era coberto por metade ou mais dos acordos coletivos da amostra. 
Ao longo do período, predominou o crescimento no número de çáusulas substantivas. Este tipo de cláusula correspondia a 50,4\% do total em 1978, tendo chegado a 83,5\% em 1995 (79,8\% para todo o período 1978-95). A maior parte das cláusulas substantivas versou sobre o tema da remuneração, oscilando em torno de um terço do total ao longo do período. Outros temas relevantes sobre a regulação da relação de emprego compreenderam a jornada de trabalho (10,3\% do total de cláusulas entre 1978 e 1995), férias e licenças remuneradas $(6,3 \%)$, recrutamento e contrato de trabalho $(6,4 \%)$, segurança no emprego e rescisão do contrato de trabalho (14,3\%), e condições de trabalho $(8,6 \%)$.

As cláusulas de procedimento responderam por $20,2 \%$ do número total de cláusulas no período 1978-95. Estas normas cobriram áreas tais como relações sindicais $(7,3 \%$ do total de cláusulas entre 1978 e 1995), procedimentos de negociação e de resolução de conflitos $(2,3 \%)$, normas complementares sobre o acordo coletivo (3,4\%), sanções $(3,7 \%)$, e finanças de sindicatos de empregadores $(3,4 \%)$.

O crescimento expressivo no número de cláusulas e o alargamento do escopo temático dos acordos sugerem uma mudança na regulação das relações de trabalho a partir de fins dos anos 1970 . O papel desempenhado pelas negociações coletivas fortaleceu-se em comparação ao estado de anemia em que se encontrava e ao predomínio quase absoluto dos modos de regulação estatal e unilateral pelos empregadores.

\section{Referências Bibliográficas}

BAMBER, G. e CÓRDOVA, E. Collective bargaining. In: R. Blanpain e C. Engels (orgs.). Comparative labour law and industrial relations in industrialized market economies. $5^{\text {a }}$ ed. Deventer-Boston: Kluwer, 1993.

BRANDÃO, S. M. C. Política salarial e negociações coletivas: o caso das categorias metalúrgica, química e têxtil do município de São Paulo - 1978/1989. Dissertação de Mestrado, Universidade Estadual de Campinas, 1991.

BURCHILL, F. Labour relations. $2^{\mathrm{a}}$ ed. London: Macmillan, 1997.

CÓRDOVA, E. From corporatism to liberalisation: the new directions of the Brazilian system of industrial relations. Labour and Society, 14, 3, p. 251-269, abril, 1989.

DEAKIN, S. e MORRIS, G. S. Labour law. Londres: Butterworths, 1995. 
DIEESE. Manual de codificação-Sistema de Acompanhamento da Contratação Coletiva. Fotocópia. São Paulo: Departamento Intersindical de Estatística e Estudos Sócio-Econômicos, 1995.

DUNLOP, J. T. Industrial relations systems. Ed. revista. Boston: HBS Press, 1993.

DUNN, S. e WRIGHT, M. Maintaining the 'status quo'? An analysis of the contents of British collective agreements, 1979-1990. British Joumal of Industrial Relations, 32, 1, p. 23-46, março, 1994.

DUNNING, H. Negotiating and writing a collective agreement. Genebra: ILO, 1985.

FLANDERS, A. Management and unions: the theoryand reform of industrial relations. Londres: Faber and Faber, 1970.

GREEN, G. D. Industrial relations: text and case studies $4^{\mathrm{a}}$ ed. Londres: Pitman, 1994.

GRUBB, D. e WELLS, W. Employment regulation and patterns of work in EC countries. OECD Economic Studies, 21, p. 7-58, inverno, 1993.

HORN, C. H. V. A determinação dos salários e o poder de barganha dos sindicatos: mudança estrutural e resultados das negociações dos bancários de Porto Alegre entre 1979 e 1988. Dissertação de Mestrado, Universidade Federal do Rio Grande do Sul, 1992.

PRADO, A. Mudanças na negociação sindical nos anos recentes. São Paulo em Perspectiva, 12, 1, p. 30-34, janeiro-março, 1998.

STOREY, J. The challenge to management control. Londres: Kogan Page, 1980.

VASCONCELLOS, M. A. S. A ação dos sindicatos e os diferenciais de salários: 197982. Tese de Doutorado, Universidade de São Paulo, 1983.

WINDMULLER, J. P. Comparative study of methods and practices. In: J. P. Windmuller et al, Collective bargaining in industrialized market economies: a reappraisal. Genebra: ILO, 1987.

WOOD, S. J. et al. Rules in industrial relations theory: a discussion. Industrial Relations Joumal, 6, 1, p. 14-30, primavera, 1975. 